\title{
Comparative phylogeography of codistributed species of Chilean Liolaemus (Squamata: Tropiduridae) from the central-southern Andean range
}

\author{
Byron J. Adams \\ byron_adams@byu.edu \\ Pedro F. Victoriano \\ Juan Carlos Ortiz \\ Edgar Benavides \\ Jack W. Sites \\ Follow this and additional works at: https://scholarsarchive.byu.edu/facpub \\ Part of the Microbiology Commons
}

\section{Original Publication Citation}

Victoriano, Pedro F., Juan Carlos Oritz, Edgar Benavides, Jack W. Sites Jr, and Byron J. Adams. "Comparative phylogeography of codistributed species of Chilean Liolaemus (Squamata: Tropiduridae) from the central-southern Andean range," Molecular Biology (28) 1-2.

\section{BYU ScholarsArchive Citation}

Adams, Byron J.; Victoriano, Pedro F.; Ortiz, Juan Carlos; Benavides, Edgar; and Sites, Jack W., "Comparative phylogeography of codistributed species of Chilean Liolaemus (Squamata: Tropiduridae) from the central-southern Andean range" (2008). Faculty Publications. 880.

https://scholarsarchive.byu.edu/facpub/880

This Peer-Reviewed Article is brought to you for free and open access by BYU ScholarsArchive. It has been accepted for inclusion in Faculty Publications by an authorized administrator of BYU ScholarsArchive. For more information, please contact ellen_amatangelo@byu.edu. 


\title{
Comparative phylogeography of codistributed species of Chilean Liolaemus (Squamata: Tropiduridae) from the central-southern Andean range
}

\author{
PEDRO F. VICTORIANO,* JUAN CARLOS ORTIZ,*EDGAR BENAVIDES,†BYRON J. ADAMS \\ and JACK W. SITES JR+ \\ *Departamento de Zoología, Facultad de Ciencias Naturales y Oceanográficas, C.I.E.P. Universidad de Concepción, Casilla 160-C, \\ Concepción, Chile, tDepartment of Biology and M.L. Bean Life Science Museum, Brigham Young University, Provo, UT 84602, USA, \\ $\ddagger$ Department of Microbiology and Molecular Biology, and Evolutionary Ecology Laboratories, Brigham Young University, Provo, \\ UT 84602, USA
}

\begin{abstract}
In this study, we used a recently developed supertrees method to test for shared phylogeographical signal in partially overlapping geographical ranges of lizards of the genus Liolaemus from the Andean Range in south-central Chile. We reconstruct mtDNA gene trees for three partially codistributed species (Liolaemus tenuis, L. lemniscatus and L. pictus), and our sampling effort is sufficient to allow statistical tests of shared signal between the combinations L. tenuis-L. pictus, and L. tenuis-L. lemniscatus. For both combinations, standardized maximum agreement subtrees scores showed statistically significant signal for shared pattern in regions of overlap, as evaluated by randomization tests $(P<0.001$ and $<0.05$, respectively). The matrix representation with parsimony tree obtained from the combination of the three different gene trees revealed concordant phylogeographical associations of all species, and was consistent with the geographical association of intraspecific haploclades with three Chilean bioclimatic zones. A multidimensional scaling analysis of several climate variables showed highly significant differences among these zones, which further suggests that they may have contributed to similar patterns of intraspecific divergence across all three species. In the mesomorphic zone in Central Chile, the species L. tenuis and L. lemniscatus may have codiverged in response to shared orogenic vicariant events, which likely predominated over climatic events associated with cycles of glacial advance and retreat. In the hygromorphic zone in southern Chile, however, glacial cycles likely predominated in structuring the phylogeographical histories of L. tenuis and L. pictus, although important ecological differences between these two caution against broad generalizations at this point.
\end{abstract}

Keywords: Andes, Chile, comparative phylogeography, Liolaemus, lizard, maximum agreement subtrees, mtDNA

Received 15 September 2007; revision accepted 18 February 2008

\section{Introduction}

Comparative phylogeography is becoming an increasingly important subdiscipline of biogeography focused on reconstruction of the evolutionary history of ecological associations and communities on a regional scale (Bermingham \&

Correspondence: Pedro F. Victoriano, Departamento de Zoología, Facultad de Ciencias Naturales y Oceanográficas, Barrio Universitario, Casilla 160-C, Universidad de Concepción, Concepción, Chile. Fax: 56412389 82; E-mail: pvictori@udec.cl
Moritz 1998; Arbogast \& Kenagy 2001). The methods of comparative phylogeography typically do this in two steps; the first is to reconstruct the evolutionary histories of two or more codistributed species within a region of interest, and then determine whether some parts of these shared histories reflect common responses to the same historical events. While the first step of this general approach (phylogenetic inference) is relatively well-developed, the actual comparative component of evaluating evolutionary histories of multiple species for signal of a shared response to the same historical events (orogenies, marine 
transgressions, glacial cycles, volcanism, etc.) has until recently been largely descriptive and qualitative. This is beginning to change as new methodologies permit tests of a priori hypotheses in regions where sufficient background information permits the formulation of explicit alternatives that can be distinguished with statistical rigor (Carstens et al. 2005). Continued refinement of methods will be extremely useful for exploring different models of speciation and other historical processes (Carstens \& Richards 2007), and also for identifying areas of endemism, high species richness, and geographical foci of evolutionary processes for conservation planning (Moritz 2002; Rissler et al. 2006).

Ideal study systems include taxa that share broadly overlapping distributions and a common history in the same region for a sufficient time to accumulate signal tracking the history (Zink 2002). In these cases, congruent patterns of evolutionary divergence will be evident in the phylogenies of the codistributed species if the shared signal has not been erased by more recent, species-specific idiosyncratic events. The strongest evidence for shared signal requires divergence in both spatial and temporal contexts (Donoghue \& Moore 2003).

One challenge to obtaining estimates of spatial divergence has been the requirement that taxa be codistributed, but recent methods accommodate statistical tests of shared phylogeographical signal between taxa having only partially overlapping geographical distributions using a supertree approach (Lapointe \& Rissler 2005; see Bininda-Emonds 2004 for a general review of supertrees). Here, we apply this approach (LR05 hereafter) to three species of Liolaemus from the complex landscapes comprising the Pacific flank of the Andean Range in south-central Chile. This requires that we: (i) obtain well-resolved and strongly supported hypotheses of relationships within each of the three species of Liolaemus based on reasonable sampling throughout their ranges; and (ii) use these genealogies to implement the LR05 approach to see if any combinations of species show significant spatial codivergence. Even with a finding of spatial codivergence, we recognize that we cannot discriminate among all possible alternative explanations for a shared pattern. Rather, we consider this a 'hypothesisgenerating' study in the context described by Avila et al. (2006); in poorly known taxa and/or regions for which background data are insufficient to generate plausible alternative a priori hypotheses, 'first pass' studies are needed to generate one or more plausible hypotheses. These may then be followed by studies that require collection of multiple classes of data [i.e. nuclear genes (Carsten \& Knowles 2007), bioclimatic or palaeo-ecological variables (Hugall et al. 2002; Carstens \& Richards 2007), etc.], and then specifying and testing a number of alternative historical hypotheses that approximate biological reality (but not so many that spurious findings become likely; Johnson \& Omland 2004).

\section{The study region and target species}

The western slope of the central Chilean Andes exhibits some historical and physical features suitable for these kinds of studies because the region is characterized by extreme topographic relief, high species endemism in multiple groups (Smith-Ramirez 2004), and it has experienced a complex palaeoclimatic and geomorphological history. Some examples are the tectonic uplift of the Andes over the last 23 million years, beginning during the Miocene and continuing to the present (Ramos 1989), and periodic global cooling during the Pleistocene (1.8 million years ago to14 000 years ago) which produced multiple shifts in climate, landscape, and sea level. At maximum advance during this last glacial period, an ice sheet covered an extensive region of southern Chile and would have excluded much of the terrestrial biota from a large part of the southern Andes (Fig. 1). Several species of squamate reptiles now occur in this area, and many of these have almost certainly experienced the same palaeoclimatic and geomorphological histories.

The lizard genus Liolaemus Wiegmann 1834, is represented in Chile by 76 recognized species, four of which are polytypic and give a total of 85 taxa (Pincheira-Donoso \& Núñez 2005). The heterogeneity of the Chilean territory, with pronounced latitudinal and altitudinal climatic and ecological gradients, implies that widely distributed species of Liolaemus are adapted to very different environmental regimes. The high species richness, high endemism, and the frequently observed extensive intraspecific morphological variation in widely distributed species collectively suggests that this genus has been a dynamic group in an evolutionary sense - it has likely speciated extensively in response to a combination of recent and ancient tectonic and climatic changes in this part of South America. Several species of Liolaemus are abundant and have sympatric and sometimes syntopic distributions (Donoso-Barros 1966; Nuñez \& Jaksic 1992), and Chilean species represent several distinct clades of the genus (Schulte et al. 2000). Furthermore, many species differ in key features of their life histories (habitat preference, parity mode, etc.), so closely related and distantly related species, with similar and different ecologies, often occur in sympatry. This collection of attributes makes the group well-suited for comparative phylogeographical studies.

Here, we chose three focal species for comparative phylogeographical study because of their accessibility in the field, well-defined geographical distributions, and a high level of geographical codistribution between different combinations of species. The species include: Liolaemus tenuis (Dumeril \& Bibron 1837), Liolaemus pictus (Dumeril \& Bibron (1837), and Liolaemus lemniscatus (Gravenhorst 1838). These species are phylogenetically members of the same clade (i.e. the subgenus Liolaemus), but L. lemniscatus and L. tenuis are much more closely related to each other than either is to L. pictus (Schulte et al. 2000). Of these, the arboreal 


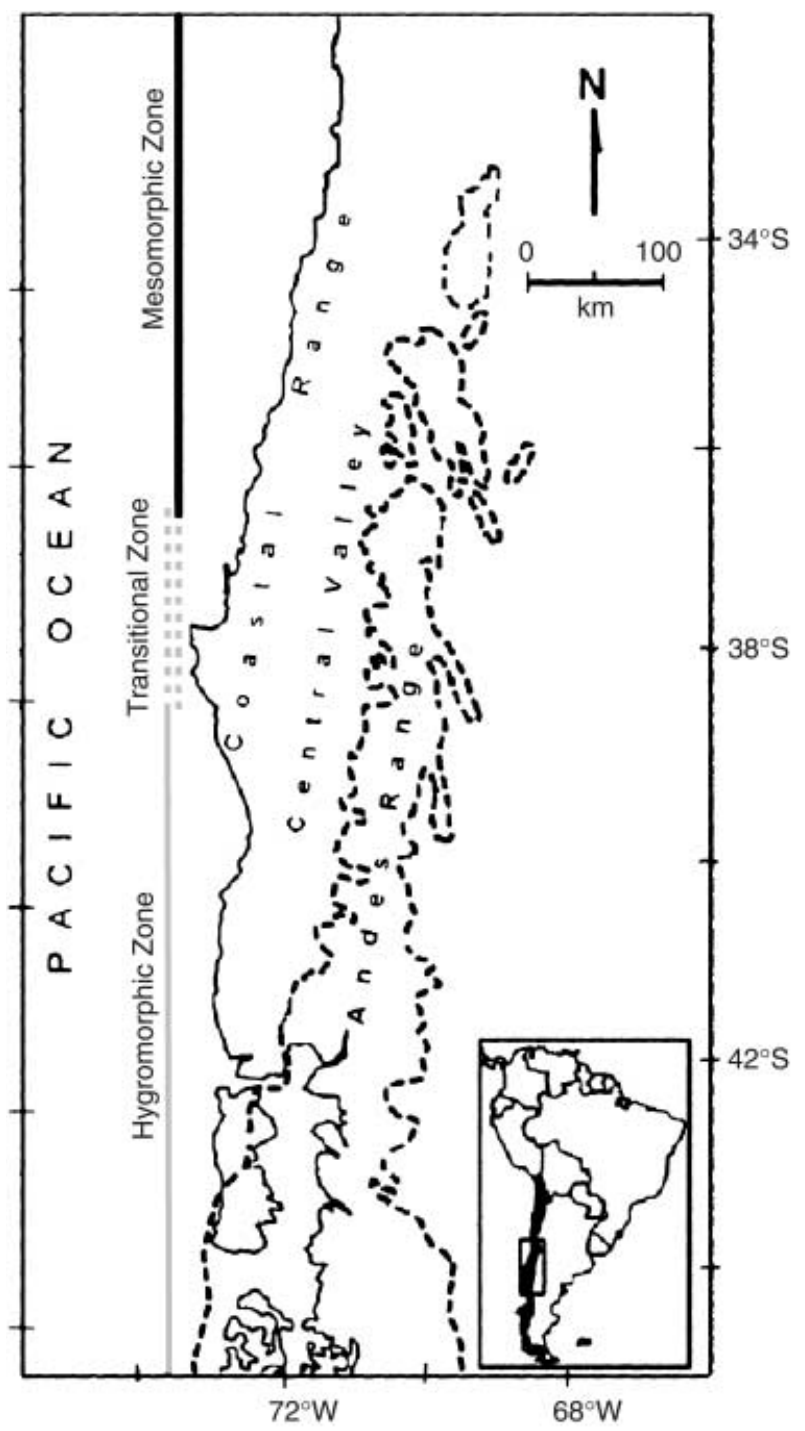

Fig. 1 Distribution of the ice shield during the LGM (dashed line) and the approximate latitudinal extent of the three Chilean biogeographical zones (mesomorphic, transitional, and hygromorphic) considered in this study.

L. tenuis has the largest distribution, ranging from Coquimbo $\left(29^{\circ} 58^{\prime} \mathrm{S}, 71^{\circ} 21^{\prime} \mathrm{W}\right)$ south to Los Lagos (39 $51^{\prime} \mathrm{S}, 72^{\circ} 50^{\prime} \mathrm{W}$; Fig. 2a), and altitudinally extending from sea level to $1800 \mathrm{~m}$ (Donoso-Barros 1966; Vidal et al. 2004, 2005a); this distribution covers bioclimatic and ecological conditions ranging from Mediterranean to sub-Andean (Di Castri 1968), and includes areas that were glaciated during the last glacial maximum (LGM; Lowell et al. 1995). Its distribution is associated with grassland and shrub habitats in the mesomorphic zone (Donoso-Barros 1966), and the species is oviparous (Cei et al. 2003).

The more terrestrial L. lemniscatus (also oviparous) is associated with warmer and drier environments than $L$. tenuis (Lamborot \& Ortiz 1990; Pincheira-Donoso \& Nuñez 2005), and ranges from La Serena $\left(30^{\circ} \mathrm{S}\right)$ south to the Biobío River (38 ${ }^{\circ}$; Fig. 2c), and altitudinally from 250 to $1400 \mathrm{~m}$. Finally, L. pictus ranges from the Biobío region $\left(\sim 37^{\circ} \mathrm{S}\right)$ south to Chiloé

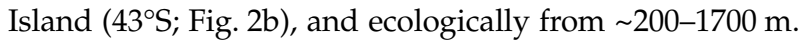
It is an arboreal lizard found in the Nothofagus forest from the transitional to hygromorphic zones in Chile, and the conifer woodlands of southern Neuquen and northern Rio Negro provinces in Argentina (Martins et al. 2004). This species is viviparous (Donoso-Barros 1966; Cei et al. 2003; Vidal et al. 2005b), and likely most tolerant of the three species to cold and humidity. This species is the most likely candidate to persist during the LGM fragmentation (Vidal et al. 2005b).

These species overlap latitudinally from the Biobío region $\left(\sim 37^{\circ} \mathrm{S}\right)$ south to Llanquihue $\left(\sim 42^{\circ} \mathrm{S}\right)$, and two (L. tenuis and L. lemniscatus) overlap from Coquimbo $\left(\sim 30^{\circ} \mathrm{S}\right)$ to the Biobío River (Fig. 2). In combination, this represents in a shared latitudinal distribution of over $1000 \mathrm{~km}$.

\section{Materials and methods}

\section{Taxon sampling}

Lizards were collected in the field by hand or noose, euthanized, and preserved as museum vouchers in the Monte L. Bean Life Science Museum at Brigham Young University (BYU), and in the Museo de Zoologia, Universidad de Concepción (MZUC). We collected a total of 278 lizards from 61 localities (Fig. 3a) in the following species proportions: 144 individuals of Liolaemus tenuis (from 41 localities), 82 Liolaemus pictus (15 localities), and 52 Liolaemus lemniscatus from 14 sites (Table 1; Fig. 3a). Three species (Liolaemus chiliensis, Liolaemus cyanogaster and Liolaemus monticola) were chosen as outgroup taxa on the basis of relationships reported by Schulte et al. (2000). Table 1 summarizes the number of individuals collected per locality and other distributional information for each species considered in this study.

\section{Laboratory protocols}

Total genomic DNA was extracted from muscle tissue preserved in $96 \%$ ethanol, following the protocol developed by Fetzner (1999), and using the QIAGEN DNeasy tissue kit according to the standard protocol. Three microlitres of extraction products were separated by electrophoresis on a $1 \%$ agarose gel to assess DNA quality, and samples were diluted if necessary before polymerase chain reaction (PCR) amplification. Two mitochondrial gene regions were amplified via PCR in a 'cocktail' containing $2.0 \mu \mathrm{L}$ of template DNA (approximate concentration estimated on a $2 \%$ agarose gel), $8 \mu \mathrm{L}$ of $\mathrm{dNTPs}(1.25 \mathrm{~mm}), 4 \mu \mathrm{L}$ of $10 \times$ Taq buffer, $4 \mu \mathrm{L}$ of each primer $(10 \mu \mathrm{M}), 4 \mu \mathrm{L}$ of $\mathrm{MgCl}(25 \mathrm{~mm})$, $24 \mu \mathrm{L}$ of distilled water and $0.25 \mu \mathrm{L}$ of Taq DNA polymerase $(5 \mathrm{U} / \mu)$ from Promega Corp. The gene regions used include 


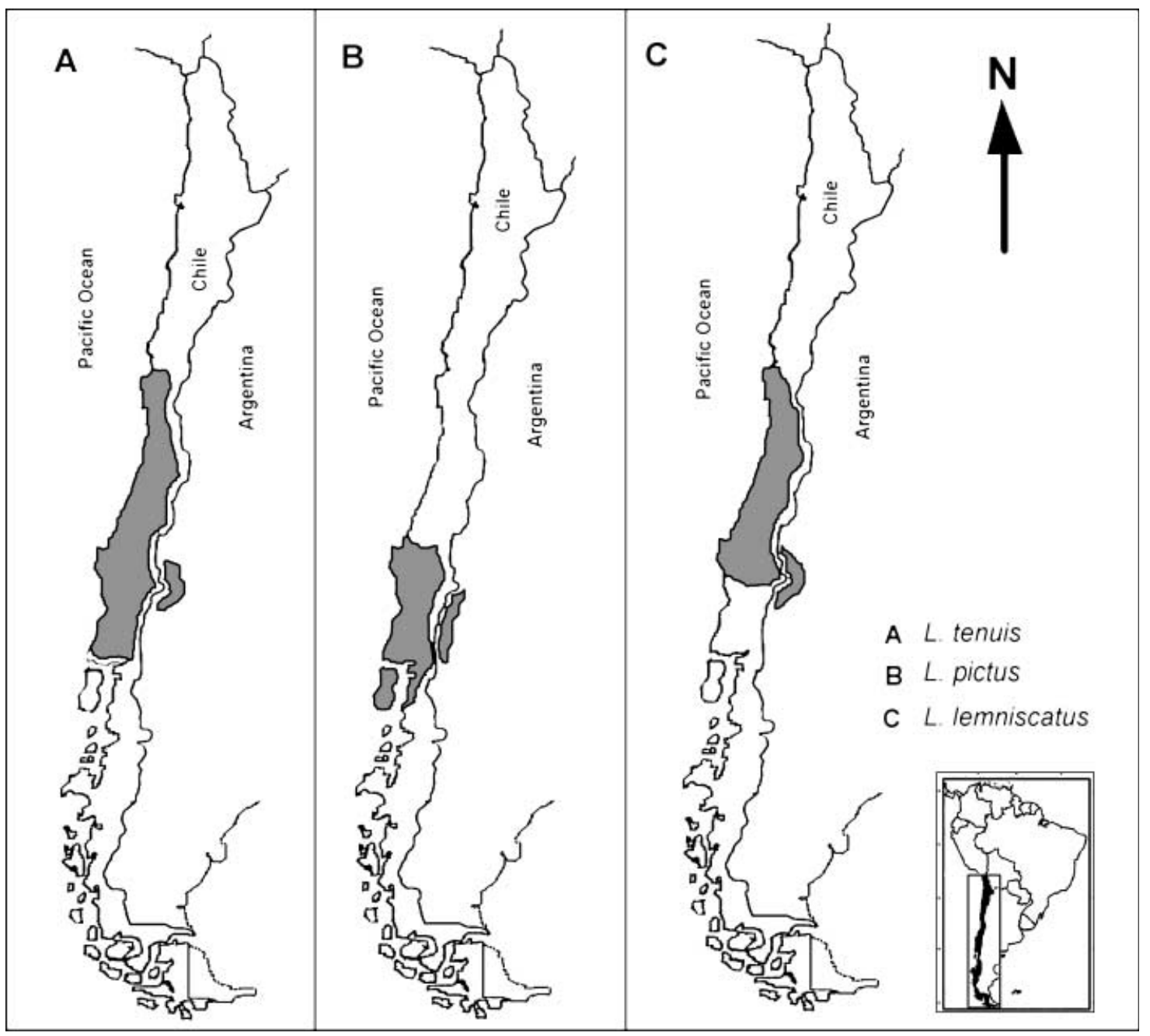

Fig. 2 Geographical distribution of the three species of Liolaemus analysed in this study.

(i) a fragment of $\sim 760$ bp of the cytochrome $b$ (cyt $b$ ) gene, and (ii) a fragment of $\sim 740$ bp of the $12 S$ gene. For cyt $b$, we used light strand primers GluDGL (5'-TGACTTGAARAA CCAYCGTTG-3'; Palumbi 1996), F1 (5'-TGAGGACARATAT CHTTYTGRGG-3'), and heavy strand cyt $b 3$ (5'-GGCAA ATAGGAARTATCATTC-3'; Palumbi 1996). For the $12 \mathrm{~S}$ gene, we used the 12e (5'-GTRCGCTTACCWTGTTACG ACT-3') and tPhe (5'-AAAGCACRGCACTGAAGATGC-3') primers of Wiens et al. (1999).

Double-stranded PCR products were checked by electrophoresis on $2 \%$ agarose gels, purified using a GeneClean III kit (BIO 101, Inc.), and directly sequenced bidirectionally using the PerkinElmer ABI PRISM Dye Terminator Cycle Sequencing Ready Reaction (PE Applied Biosystems). Excess Dye Terminator was removed with CentriSep spin columns (Princeton Separations Inc.), and sequences then fractionated by polyacrylamide gel electrophoresis on a ABI PRISM 377 automated DNA sequencer (PE Applied Biosystems) at the DNA Sequencing Center at Brigham Young University.

\section{Sequence alignments}

Sequences were edited and aligned with SEQUENCHER 4.2 (Gene Codes Corp. Inc. 1995), and the protein coding region cyt $b$ was translated into amino acids for confirmation of alignment. Divergence was lower for the $12 \mathrm{~S}$ fragment and the number of indels was small, typically single base differences, except for one 6-bp indel in L. pictus. The alignment of this region was performed with CLUSTAL_x (Thompson et al. 1997) using default settings for gap and mismatch penalties, with subsequent manual adjustments that maintain base-pair identity in conserved nucleotide blocks. Missing data were coded as '?'. Sequences were deposited in GenBank under accession numbers EU649101EU649413). Additional sequences for $12 \mathrm{~S}$ of L. tenuis (code AY662055) and cyt $b$ and $12 S$ of L. pictus (codes AY367791 and AY367820, respectively) from Alumine Province of Neuquen, Argentina, were obtained from GenBank. Recent studies on Argentinian groups of 

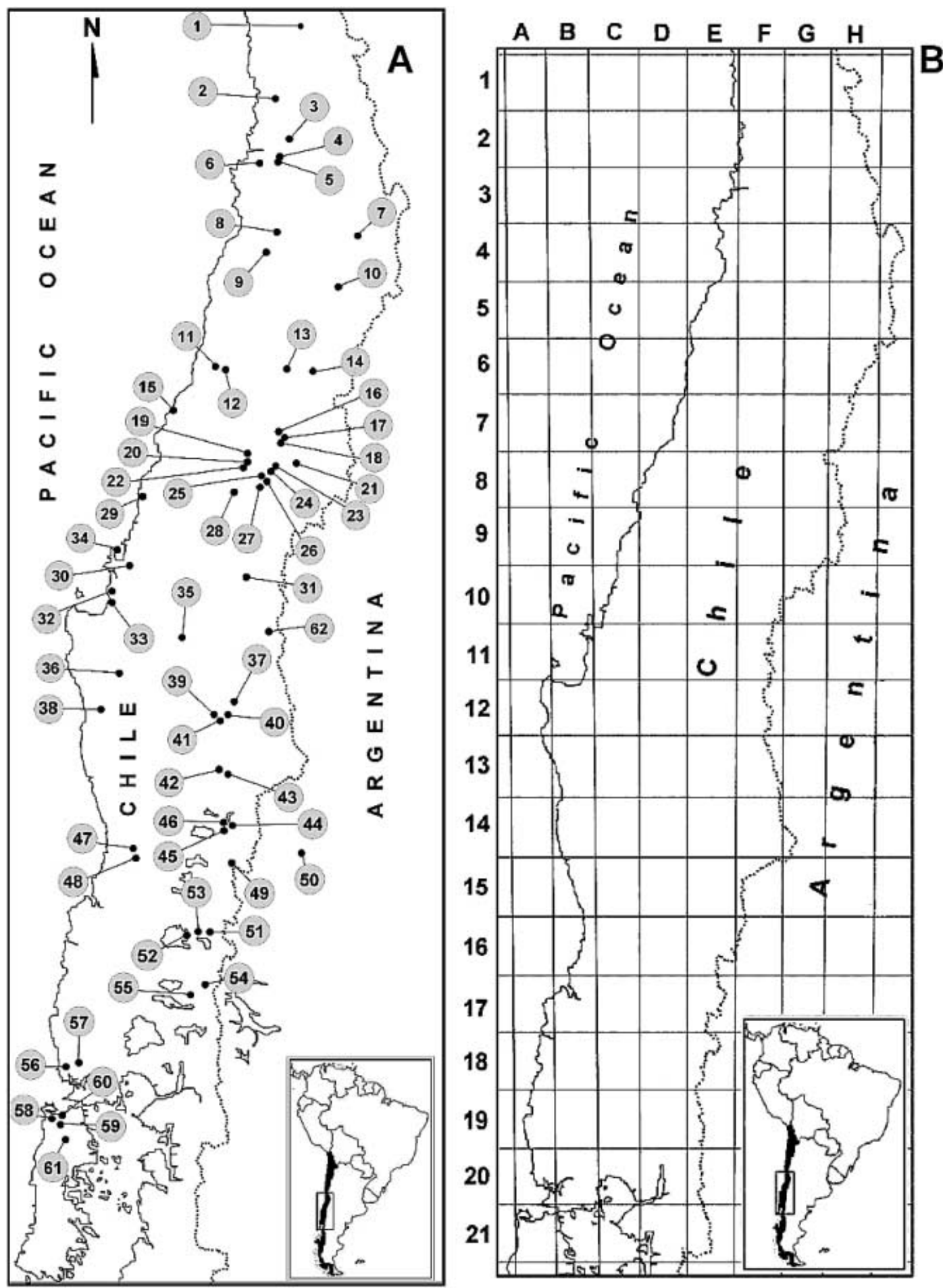

Fig. 3 (a) Geographical distribution of the samples included in this study; black dots identify localities, and locality numbers correspond to those summarized in Table 1. (b) Grid for areas used in the supertrees analysis; each square is a half degree on a side, and these are identified by letter $\times$ number codes (i.e. G1, F2) which are summarized in Table 1 .

Liolaemus (Morando et al. 2003, 2004, 2007; Avila et al. $2004,2006)$ show that mtDNA cyt $b$ and $12 S$ gene regions were both informative at intraspecific and interspecific levels.
Gene tree phylogenies for individual species

Phylogenetic analyses followed in part our earlier studies of Liolaemus (Morando et al. 2003, 2004; Avila et al. 2006); 
6 P. F. VICTORIANO ET AL.

Table 1 List of localities, sample sizes, and grid codes for the samples used in the supertrees analysis; site numbers are plotted in Fig. 3a, and area codes in Fig. 3b

\begin{tabular}{|c|c|c|c|c|c|}
\hline Species & Site no. & Locality name & Geographical coordinates & Sample size & Area code \\
\hline \multicolumn{6}{|c|}{ Liolaemus tenuis } \\
\hline & 1 & Salamanca & $31^{\circ} 46^{\prime} \mathrm{S}, 70^{\circ} 57^{\prime} \mathrm{W}$ & 3 & G1 \\
\hline & 2 & La Ligua & $32^{\circ} 28^{\prime} \mathrm{S}, 71^{\circ} 30^{\prime} \mathrm{W}$ & 4 & $\mathrm{~F} 2$ \\
\hline & 4 & Cementerio Olmue & $32^{\circ} 59^{\prime} \mathrm{S}, 71^{\circ} 11^{\prime} \mathrm{W}$ & 7 & F3 \\
\hline & 5 & Olmue & $33^{\circ} 00^{\prime} \mathrm{S}, 71^{\circ} 12^{\prime} \mathrm{W}$ & 1 & F3 \\
\hline & 6 & Quilpue & $33^{\circ} 02^{\prime} \mathrm{S}, 71^{\circ} 25^{\prime} \mathrm{W}$ & 5 & E3 \\
\hline & 7 & Cajon del Maipo & $33^{\circ} 39^{\prime} \mathrm{S}, 70^{\circ} 4^{\prime} \mathrm{W}$ & 1 & $\mathrm{H} 4$ \\
\hline & 8 & Melipilla & $33^{\circ} 42^{\prime} \mathrm{S}, 71^{\circ} 13^{\prime} \mathrm{W}$ & 7 & F5 \\
\hline & 10 & Coya & $34^{\circ} 12^{\prime} \mathrm{S}, 70^{\circ} 32^{\prime} \mathrm{W}$ & 4 & G5 \\
\hline & 12 & Hualaňe & $34^{\circ} 58^{\prime} \mathrm{S}, 71^{\circ} 49^{\prime} \mathrm{W}$ & 5 & E7 \\
\hline & 13 & Romeral & $34^{\circ} 58^{\prime} \mathrm{S}, 71^{\circ} 7^{\prime} \mathrm{W}$ & 4 & F7 \\
\hline & 14 & Los Queňes & $34^{\circ} 59^{\prime} \mathrm{S}, 70^{\circ} 49^{\prime} \mathrm{W}$ & 8 & G7 \\
\hline & 15 & Constitucion & $35^{\circ} 19^{\prime} \mathrm{S}, 72^{\circ} 25^{\prime} \mathrm{W}$ & 2 & D8 \\
\hline & 17 & Vilches & $35^{\circ} 35^{\prime} \mathrm{S}, 71^{\circ} 5^{\prime} \mathrm{W}$ & 4 & F8 \\
\hline & 18 & Alto Vilches & $35^{\circ} 35^{\prime} \mathrm{S}, 71^{\circ} 25^{\prime} \mathrm{W}$ & 1 & F8 \\
\hline & 19 & Yerbas Buenas & $35^{\circ} 45^{\prime} \mathrm{S}, 71^{\circ} 34^{\prime} \mathrm{W}$ & 3 & E9 \\
\hline & 20 & Linares & $35^{\circ} 50^{\prime} \mathrm{S}, 71^{\circ} 34^{\prime} \mathrm{W}$ & 4 & E9 \\
\hline & 22 & SurOeste Linares & $35^{\circ} 51^{\prime} \mathrm{S}, 71^{\circ} 35^{\prime} \mathrm{W}$ & 4 & E9 \\
\hline & 24 & Embalse Ancoa & $35^{\circ} 54^{\prime} \mathrm{S}, 71^{\circ} 17^{\prime} \mathrm{W}$ & 1 & F9 \\
\hline & 26 & Longavi & $35^{\circ} 56^{\prime} \mathrm{S}, 71^{\circ} 23^{\prime} \mathrm{W}$ & 1 & E9 \\
\hline & 28 & Norte de Parral & $35^{\circ} 58^{\prime} \mathrm{S}, 71^{\circ} 28^{\prime} \mathrm{W}$ & 1 & E9 \\
\hline & 29 & Cobquecura & $36^{\circ} 08^{\prime} \mathrm{S}, 72^{\circ} 46^{\prime} \mathrm{W}$ & 6 & C9 \\
\hline & 30 & Nonguen & $36^{\circ} 47^{\prime} \mathrm{S}, 72^{\circ} 55^{\prime} \mathrm{W}$ & 4 & $\mathrm{C} 11$ \\
\hline & 31 & Las Trancas & $36^{\circ} 53^{\prime} \mathrm{S}, 71^{\circ} 34^{\prime} \mathrm{W}$ & 5 & E11 \\
\hline & 33 & Lota & $37^{\circ} 05^{\prime} \mathrm{S}, 73^{\circ} 10^{\prime} \mathrm{W}$ & 1 & B11 \\
\hline & 34 & Isla Quiriquina & $37^{\circ} 20^{\prime} \mathrm{S}, 72^{\circ} 30^{\prime} \mathrm{W}$ & 8 & $\mathrm{~B} 10$ \\
\hline & 35 & Los Angeles & $37^{\circ} 23^{\prime} \mathrm{S}, 72^{\circ} 1^{\prime} \mathrm{W}$ & 3 & E12 \\
\hline & 37 & Pemehue & $38^{\circ} 03^{\prime} \mathrm{S}, 71^{\circ} 43^{\prime} \mathrm{W}$ & 4 & E13 \\
\hline & 38 & Lanalhue & $38^{\circ} 07^{\prime} \mathrm{S}, 73^{\circ} 16^{\prime} \mathrm{W}$ & 4 & B13 \\
\hline & 39 & Victoria & $38^{\circ} 10^{\prime} \mathrm{S}, 71^{\circ} 57^{\prime} \mathrm{W}$ & 6 & E13 \\
\hline & 40 & Malleco & $38^{\circ} 10^{\prime} \mathrm{S}, 71^{\circ} 48^{\prime} \mathrm{W}$ & 1 & E13 \\
\hline & 41 & Malleco, Las Mentas & $38^{\circ} 12^{\prime} \mathrm{S}, 71^{\circ} 50^{\prime} \mathrm{W}$ & 4 & E13 \\
\hline & 42 & Cherquenco & $38^{\circ} 40^{\prime} \mathrm{S}, 71^{\circ} 53^{\prime} \mathrm{W}$ & 5 & E14 \\
\hline & 43 & Volcan Llaima & $38^{\circ} 41^{\prime} \mathrm{S}, 71^{\circ} 48^{\prime} \mathrm{W}$ & 1 & E14 \\
\hline & 44 & Huerquehue & $39^{\circ} 11^{\prime} \mathrm{S}, 71^{\circ} 45^{\prime} \mathrm{W}$ & 1 & E15 \\
\hline & 46 & Ribera Lago Caburgua & $39^{\circ} 10^{\prime} \mathrm{S}, 71^{\circ} 49^{\prime} \mathrm{W}$ & 2 & E16 \\
\hline & 47 & La Capilla & $39^{\circ} 25^{\prime} \mathrm{S}, 72^{\circ} 53^{\prime} \mathrm{W}$ & 5 & $\mathrm{C} 16$ \\
\hline & 48 & Calquinco & $39^{\circ} 28^{\prime} \mathrm{S}, 72^{\circ} 51^{\prime} \mathrm{W}$ & 6 & $\mathrm{C} 16$ \\
\hline & 49 & Puesco & $39^{\circ} 32^{\prime} \mathrm{S}, 71^{\circ} 43^{\prime} \mathrm{W}$ & 1 & E16 \\
\hline & 50 & Alumine, Argentina & $39^{\circ} 25^{\prime} \mathrm{S}, 70^{\circ} 53^{\prime} \mathrm{W}$ & 1 & ARG \\
\hline & 51 & Los Llolles & $40^{\circ} 11^{\prime} \mathrm{S}, 72^{\circ} 0^{\prime} \mathrm{W}$ & 1 & E18 \\
\hline & 52 & Ranco & $40^{\circ} 13^{\prime} \mathrm{S}, 72^{\circ} 16^{\prime} \mathrm{W}$ & 6 & $\mathrm{D} 18$ \\
\hline \multicolumn{6}{|c|}{ Liolaemus lemniscatus } \\
\hline & 3 & Ocoa & $32^{\circ} 49^{\prime} \mathrm{S}, 71^{\circ} 5^{\prime} \mathrm{W}$ & 4 & F5 \\
\hline & 4 & Cementerio Olmue & $32^{\circ} 59^{\prime} \mathrm{S}, 71^{\circ} 11^{\prime} \mathrm{W}$ & 1 & F3 \\
\hline & 9 & Rinconada Maipú & $33^{\circ} 52^{\prime} \mathrm{S}, 71^{\circ} 20^{\prime} \mathrm{W}$ & 3 & F5 \\
\hline & 10 & Coya & $34^{\circ} 12^{\prime} \mathrm{S}, 70^{\circ} 32^{\prime} \mathrm{W}$ & 2 & G5 \\
\hline & 11 & Hualaňe-Vichuquen & $34^{\circ} 56^{\prime} \mathrm{S}, 71^{\circ} 55^{\prime} \mathrm{W}$ & 4 & E7 \\
\hline & 14 & Los Queňes & $34^{\circ} 59^{\prime} \mathrm{S}, 70^{\circ} 49^{\prime} \mathrm{W}$ & 10 & G7 \\
\hline & 16 & Cementerio Vilches & $35^{\circ} 33^{\prime} \mathrm{S}, 71^{\circ} 12^{\prime} \mathrm{W}$ & 8 & F8 \\
\hline & 21 & Camino a Rangue & $35^{\circ} 50^{\prime} \mathrm{S}, 71^{\circ} 0^{\prime} \mathrm{W}$ & 4 & F5 \\
\hline & 23 & Robleria & $35^{\circ} 51^{\prime} \mathrm{S}, 71^{\circ} 15^{\prime} \mathrm{W}$ & 1 & F9 \\
\hline & 24 & Embalse Ancoa & $35^{\circ} 54^{\prime} \mathrm{S}, 71^{\circ} 17^{\prime} \mathrm{W}$ & 1 & F9 \\
\hline & 25 & Precordillera Linares & $35^{\circ} 55^{\prime} \mathrm{S}, 71^{\circ} 22^{\prime} \mathrm{W}$ & 3 & F9 \\
\hline & 27 & Longavi Sur & $35^{\circ} 57^{\prime} \mathrm{S}, 71^{\circ} 15^{\prime} \mathrm{W}$ & 1 & E9 \\
\hline & 32 & Coronel & $37^{\circ} 01^{\prime} \mathrm{S}, 73^{\circ} 8^{\prime} \mathrm{W}$ & 5 & B11 \\
\hline & 33 & Lota & $37^{\circ} 05^{\prime} \mathrm{S}, 73^{\circ} 10^{\prime} \mathrm{W}$ & 5 & B11 \\
\hline
\end{tabular}


Table 1 Continued

\begin{tabular}{|c|c|c|c|c|c|}
\hline Species & Site no. & Locality name & Geographical coordinates & Sample size & Area code \\
\hline \multicolumn{6}{|l|}{ Liolaemus pictus } \\
\hline & 36 & Nahuelbuta & $37^{\circ} 47^{\prime} \mathrm{S}, 73^{\circ} 3^{\prime} \mathrm{W}$ & 3 & B13 \\
\hline & 41 & Malleco, Las Mentas & $38^{\circ} 12^{\prime} \mathrm{S}, 71^{\circ} 50^{\prime} \mathrm{W}$ & 10 & E13 \\
\hline & 43 & Volcan Llaima & $38^{\circ} 41^{\prime} \mathrm{S}, 71^{\circ} 48^{\prime} \mathrm{W}$ & 11 & E14 \\
\hline & 45 & Huerquehue Sur & $39^{\circ} 12^{\prime} \mathrm{S}, 71^{\circ} 46^{\prime} \mathrm{W}$ & 2 & E16 \\
\hline & 50 & Alumine, Argentina & $39^{\circ} 25^{\prime} \mathrm{S}, 70^{\circ} 53^{\prime} \mathrm{W}$ & 1 & ARG \\
\hline & 51 & Los Llolles & $40^{\circ} 11^{\prime} \mathrm{S}, 72^{\circ} 0^{\prime} \mathrm{W}$ & 3 & E18 \\
\hline & 52 & Ranco & $40^{\circ} 13^{\prime} \mathrm{S}, 72^{\circ} 16^{\prime} \mathrm{W}$ & 1 & D18 \\
\hline & 53 & Maihue & $40^{\circ} 12^{\prime} \mathrm{S}, 72^{\circ} 6^{\prime} \mathrm{W}$ & 2 & E18 \\
\hline & 54 & Puyehue & $40^{\circ} 41^{\prime} \mathrm{S}, 72^{\circ} 0^{\prime} \mathrm{W}$ & 4 & E19 \\
\hline & 55 & Antillanca & $40^{\circ} 46^{\prime} \mathrm{S}, 72^{\circ} 12^{\prime} \mathrm{W}$ & 11 & D19 \\
\hline & 56 & Sur Oeste Estaquillas & $41^{\circ} 27^{\prime} \mathrm{S}, 73^{\circ} 44^{\prime} \mathrm{W}$ & 9 & $\mathrm{~A} 20$ \\
\hline & 57 & Estaquillas & $41^{\circ} 26^{\prime} \mathrm{S}, 73^{\circ} 41^{\prime} \mathrm{W}$ & 3 & A20 \\
\hline & 58 & Este de Ancud & $41^{\circ} 55^{\prime} \mathrm{S}, 73^{\circ} 54^{\prime} \mathrm{W}$ & 7 & $\mathrm{~A} 21$ \\
\hline & 59 & Sur de Ancud & $41^{\circ} 55^{\prime} \mathrm{S}, 73^{\circ} 50^{\prime} \mathrm{W}$ & 7 & A21 \\
\hline & 60 & Ancud & $41^{\circ} 56^{\prime} \mathrm{S}, 73^{\circ} 53^{\prime} \mathrm{W}$ & 2 & $\mathrm{~A} 21$ \\
\hline & 61 & Belben & $42^{\circ} 04^{\prime} \mathrm{S}, 73^{\circ} 45^{\prime} \mathrm{W}$ & 6 & A21 \\
\hline \multicolumn{6}{|l|}{ Outgroups: } \\
\hline Liolaemus cyanogaster & 29 & Cobquecura & $36^{\circ} 08^{\prime} \mathrm{S}, 72^{\circ} 46^{\prime} \mathrm{W}$ & 2 & $\mathrm{C} 9$ \\
\hline Liolaemus chiliensis & 31 & Las Trancas & $36^{\circ} 53^{\prime} \mathrm{S}, 71^{\circ} 34^{\prime} \mathrm{W}$ & 1 & E11 \\
\hline Liolaemus monticola & 62 & Volcan Antuco & $37^{\circ} 21^{\prime} \mathrm{S}, 71^{\circ} 6^{\prime} \mathrm{W}$ & 1 & F12 \\
\hline
\end{tabular}

redundant haplotypes were identified using COLLAPSE (version 1.1; available at: http://biology.byu.edu/faculty/ $\mathrm{kac} /$ crandall_lab/computer.html), and removed from their respective data matrices. Both single gene regions and the combined data set ( 1500 bp for both gene regions) were used for Bayesian and maximum-likelihood (ML) phylogenetic analyses on the nonredundant sequence matrixes. Trees obtained from analyses of individual gene regions and combined data sets showed almost identical topologies, and none recovered strongly supported topological conflicts (Wiens 1998) within any species, so only results of the combined analyses are included here. The program MODELTEST (version 3.04; Posada \& Crandall 1998) was used to select the best-fitting model of evolution (Akaike criterion; Posada \& Buckley 2004), for each gene region within each species. Two models were selected for cyt $b$; for L. tenuis, the model was $\operatorname{Tr} \mathrm{N}+\mathrm{I}+\Gamma$, while for L. lemniscatus and L. pictus the model was K81uf $+\mathrm{I}+\Gamma$. For $12 \mathrm{~S}$ (run separately and in the combined data set), the general time reversible model with invariable and variable sites with a discrete gamma distribution (GTR $+\mathrm{I}+\Gamma$; Yang 1994) was selected as the best-fit model for all species. All ML analyses were based on heuristic searches with 10 random addition replicates, maxtrees $=100$, and tree-bisection-reconnection (TBR) branch-swapping algorithm, as implemented in PAUP (Swofford 2002). ML bootstrap (MLB) proportions were obtained by performing five separate searches with 20 random addition replicates each, and then combining the total 100 pseudoreplicates to obtain one MLB value.
Bayesian analyses were performed using MRBAYES 2.0 (Huelsenbeck \& Ronquist 2001), based on the same models used for the ML searches. For each species, we carried out runs for 5 million generations, with four incrementally heated chains, and then sampled at intervals of 1000 generations to include 5000 data points. Stationarity was estimated by plotting (with Microsoft Excel 2003) the log-likelihood scores against generation time, and assuming stationarity when the curves flattened out. This phase was reached between 30000 and 40000 generations, depending on the species. Then, we discarded the first 30-40 trees (burn-in), and the 50\% majority-rule trees were obtained from the remaining 49704960 data points with the purpose of obtaining the posterior probability (PP) values. To avoid local entrapment on a suboptimal peak in the tree space, we performed two independent analyses, and compared these for convergence to similar log-likelihood mean values (Huelsenbeck \& Bollback 2001; Leaché \& Reeder 2002). We also compared the posterior probabilities for individual clades obtained from the separate analyses for congruence to ensure convergence of the two analyses. All phylogenetic analyses were performed on an IBM Sp2 supercomputer in the BYU supercomputing facility.

Additionally, we estimated several genetic diversity indexes for each species of Liolaemus by using all the sequences, both for each area indicated in Fig. 3b, and for each main clade obtained from the phylogenetic analysis. We estimated the haplotype (= gene) diversity $\left(H_{\mathrm{d}} ;\right.$ Nei 1987, p. 180) and nucleotide diversity $(\pi$, Nei 1987, p. 257) using DNASP 4.10 and MEGA 3.1, respectively. 


\section{Comparative phylogeography among species}

We used the phylogeographical hypotheses (individual phylogenetic trees) of the three species derived from the combined data sets, as described above, to test for topological congruence between relevant combinations of codistributed species. The LR05 method first uses maximum agreement subtrees to represent overlapping geographical regions represented in individual gene trees, and this requires that original data (gene trees for each species) be recoded to define common regional units. We did this by subdividing the sampling area into a grid system delimited as 0.25 degree square latitude/longitude squares, and coding each square with letters (longitude arrangement) and numbers (latitude arrangement; Fig. 3b). The sampling area includes three zones described in general biogeographical classifications of the Chilean territory (Pisano 1954; Mann 1964; Fig. 1a), so we further subdivided the grid into three zones corresponding to the mesomorphic zone $\left(c .29^{\circ} \mathrm{S}\right.$ to $36^{\circ} \mathrm{S}$; rows $1-9$ in Fig. $3 b)$; transitional zone $\left(c .36^{\circ} \mathrm{S}\right.$ to $38^{\circ} \mathrm{S}$; rows $10-13$ in Fig. $3 b)$; and hygromorphic zone (c. $38^{\circ} \mathrm{S}$ to $40^{\circ} \mathrm{S}$; rows 14-21 in Fig. 3b). The geographical origins of all unique haplotypes were used to define intraspecific area cladograms for each species, where different areas coded in Fig. $3 \mathrm{~b}$ were represented by one unique haplotype.

In each gene tree, all strongly supported [PP $>0.95$ (Leaché \& Reeder 2002); MLB > 70 (Hillis \& Bull 1993)] reciprocally monophyletic haploclades were pruned to a single representative sequence for each area, and then the individual haplotype names were replaced with their respective area names. The most basal haplotype in each clade was designated the semaphoront taxon. Using PAUP* (Swofford 2002), a maximum agreement subtree (MAST) was established for each pairwise combination of area trees; MASTs are appropriate to compare trees bearing different numbers of 'leaves' representing partially overlapping regions (grids in this study; see Lapointe \& Rissler 2005). For each pairwise comparison (of individual gene trees), the size of each MAST was used as a congruence index (the larger the MAST, the more congruent the two area trees are). These values were normalized for each comparison by dividing the size of the respective MAST by the number of areas common to both trees, and then compared to the distribution frequency of the MAST scores of 1000 randomly generated trees (Markov model) with an equal number of shared areas as the original MAST. The concordance of area trees was tested using TREEMAP 1.0b (Page 1994) by treating co-occurring taxa as host-parasite associations. Congruence of area trees was inferred when the test was significant (i.e. larger than randomly generated MAST scores, $95 \%$, for $P=0.05$ ). In order to test whether coalescent events among codistributed taxa are correlated, times to coalescence (of codistributed taxa) for codivergent nodes (in units of genetic distance) were plotted using TREEMAP 1.0 (Page 1994). Each pair of codiverging nodes were compared using Spearman's rho (two-tailed) test where $N$ is the number of pairs of coalescing nodes (alpha $=0.05$ ).

Pairs of area trees that were statistically more concordant than expected by chance alone were combined using matrix representation with parsimony (MRP with triple fit; see Bininda-Emonds 2004 for other kinds of supertrees); MRP was chosen because it is not biased by the shape of the input trees (Wilkinson et al. 2005). The supertree summarizes geographical areas that correspond to clade breaks in multiple taxa with unique ecological and life-history characteristics, providing evidence for a shared history of vicariant isolation or selection. This analysis was implemented using RADCON version 1.1.6 (Thorley \& Page 2000). Because influential physical factors may have played a role in generating such patterns, a second prediction made by the LR05 method is that, if multiple source trees are congruent (i.e. if they show signs of shared historical processes), then phylogeographical regions defined in a supertree will be statistically different with respect to climatic variables. In these tests, absence of congruence among source trees would lead to a supertree with no phylogeographical signal and in turn, with no relationship to climatic factors (Lapointe \& Rissler 2005, p. 291).

To quantify climate variables for the geographical areas considered in the supertree, we used a multivariate analysis to summarize six variables recorded from 85 meteorological stations located throughout the study area (taken from Amigo \& Ramírez 1998). In areas represented by more than one weather station, we used the most centrally located station in each geographical area represented in the supertree. The climatic variables are: $T$, annual mean temperature; $M$, mean daily maximum temperature of the coldest month; $m$, mean daily minimum temperature of the coldest month; $I_{c^{\prime}}$ index of continentality or thermal amplitude (calculated as the difference between the daily mean temperatures of the hottest and coldest months); $P$, mean annual precipitation; and $T_{\mathrm{p}}=$ above zero temperature index (the sum of all the monthly mean temperatures greater than $0^{\circ} \mathrm{C}$, multiplied by 10$)$.

A nonmetric multidimensional scaling (MDS) analysis, derived from Euclidean distance similarity matrices, was used to visualize dissimilarities between the same areas included in the supertree (based in the six climatic variables). All data were log-transformed and normalized before analysis. Each area was assigned to one of the three classical biogeographical zones for Chile, and this feature was considered an independent factor in the analysis. The results were further tested for significance using analysis of similarity (PRIMER version 6 ANOSIM; Clarke \& Gorley 2005), which is analogous to a univariate ANOvA and reflects differences between treatment groups (the three Chilean biogeographical zones) in contrast to differences among 
replicates within groups (the $R$ statistic). Under the null hypothesis ('no difference between groups'), $R=0$, and this was tested by a nonparametric permutation; there should be little or no effect on the average $R$ value if the labels identifying which replicates belong to which samples are randomly rearranged (Clarke 1999). Finally, the PRIMER version 6 BIO-ENV routine linking multivariate patterns was used to identify 'influential parameters' on the arrangement obtained from MDS. This is a nonparametric correlation between two distance matrices. We obtained one matrix of distances between geographical areas in the supertree topology from the number of steps between areas in the nonrooted supertree, and log-transformed these numbers before the analysis. The second matrix was based on the same log-transformed and normalized climatic data used in the previous MDS. The BIO-ENV method assigns hierarchical correlation values both to each individual climatic variable and for combinations of them.

\section{Results}

\section{General patterns of variation}

We obtained 68 unique haplotypes (combined gene regions) for Liolaemus tenuis, and 59 and 37 nonredundant haplotypes for Liolaemus pictus and Liolaemus lemniscatus, respectively. The ratio of unique haplotypes relative to the total number of individuals sampled for each species was 0.46 for $L$. tenuis, 0.71 for L. pictus, and 0.71 for L. lemniscatus. Weighting these indicators by the total geographical area sampled (number of localities) gives a lower estimate of mtDNA haplotype variability in L. tenuis (an average of 1.7 haplotypes per locality), compared to L. lemniscatus (2.64), and L. pictus (3.93).

Both the haplotype diversity $\left(H_{d}\right)$ and the nucleotide diversity $(\pi)$ values for each main clade and for each species are shown in Table 2 (values for each individual area are summarized in Appendix). Liolaemus tenuis showed the lowest $H_{\mathrm{d}}$ value (0.928), while estimates were identical and higher for L. lemniscatus and L. pictus, respectively. Different relative values were obtained for $\pi$, which was highest in L. tenuis $(\pi=0.074)$ and lowest in L. pictus $(\pi=0.051)$. When calculated for the major clades in each species (Table 2), a pattern of reduced genetic diversity in southern clades was detected in all three species (clades B2 in L. lemniscatus and L. pictus, and B in L. tenuis). The highest levels of variation were detected in clades B1 in L. lemniscatus and L. pictus, and in clade A1 in L. tenuis. The lowest genetic diversity was obtained for the southern localities (Clade B) of L. tenuis $\left(H_{\mathrm{d}}=0.624 ; \pi=0.002\right)$.

\section{Intraspecific phylogeographical structure}

In all three species, the intraspecific consensus trees obtained from Bayesian analyses of individual gene regions and the combined data recovered nearly identical topologies, and these trees were also topologically virtually identical to those derived from the ML analyses. In cases of non-identical topologies, differences were due either to unresolved parts of some gene trees, or conflicting structure with weak nodal support (as estimated from PP and MLB values). We conclude that there is no evidence for significant conflict between gene regions or methods within any of the species (following Wiens 1998), and present here the ML topologies with both MLB and PP estimates of nodal support. In all three cases, alternative structure of outgroup rooting options always recovered monophyletic ingroup haplotypes with strong support (MLB = 100; PP = 1.0).

Figure 4 presents the consensus of two ML trees (ln $\mathrm{L}=-7299.4293$ ) for $L$. tenuis, which is also representative of the majority rule consensus of 9977 Bayesian trees (mean $\ln \mathrm{L}=-6981$ ). Two large haploclades were recovered, the most strongly supported of which includes haplotypes from the mesomorphic and transitional zones (clade A; $\mathrm{MLB}=79$; $\mathrm{PP}=0.99$ ). The second less well-supported clade (B) includes haplotypes from the hygromorphic Zone (including one site in Argentina), some transitional zone haplotypes and two from the mesomorphic locality (E7 square). Within this arrangement, inclusion of the E7 area (clade B) was uniquely inconsistent with its geographical location, but placement of E7 in this clade receives only moderate support $(\mathrm{MLB}=83, \mathrm{PP}=0.76)$. The subclade monophyletic for haplotypes from the hygromorphic and transitional Zones is strongly supported (MLB = 95; PP = 1.0).

Table 2 Haplotype (gene) diversity/nucleotide diversity $(\pi ; \pm$ S.D.), for the main clades in the three species of Liolaemus; clades are identified in figures 4 to 6

\begin{tabular}{lllr}
\hline Clade & L. lemniscatus & L. tenuis & L. pictus \\
\hline A & $0.900 \pm 0.161 / 0.022 \pm 0.003$ & $0.981 \pm 0.005 / 0.060 \pm 0.005$ & $0.953 \pm 0.031 / 0.019 \pm 0.003$ \\
A1 & & $0.969 \pm 0.010 / 0.040 \pm 0.005$ & \\
A2 & $0.952 \pm 0.019 / 0.052 \pm 0.006$ & $0.985 \pm 0.006 / 0.029 \pm 0.004$ \\
B & $0.988 \pm 0.008 / 0.058 \pm 0.005$ & $0.624 \pm 0.072 / 0.002 \pm 0.001$ & $0.972 \pm 0.012 / 0.028 \pm 0.004$ \\
B1 & $0.986 \pm 0.010 / 0.049 \pm 0.004$ & & $0.952 \pm 0.096 / 0.008 \pm 0.002$ \\
B2 & $0.778 \pm 0.091 / 0.002 \pm 0.001$ & $0.928 \pm 0.017 / 0.074 \pm 0.007$ & $0.985 \pm 0.006 / 0.051 \pm 0.005$ \\
Total sp & $0.985 \pm 0.007 / 0.066 \pm 0.005$ & & \\
\hline
\end{tabular}

(C) 2008 The Authors

Journal compilation @ 2008 Blackwell Publishing Ltd 


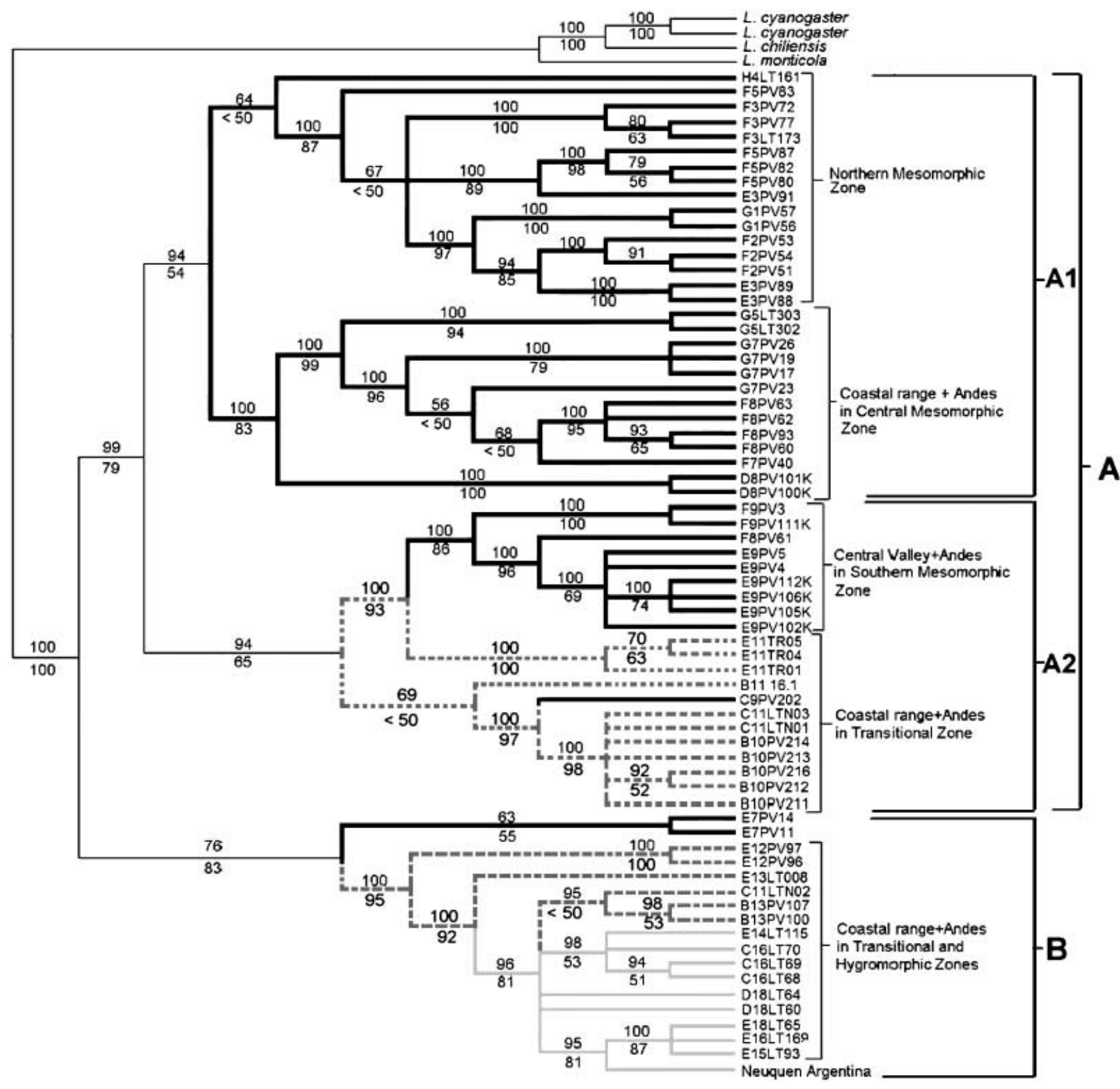

Fig. 4 Mitochondrial gene tree for Liolaemus tenuis based on ML $(\ln L=-7299.4293)$ and Bayesian analyses, constructed from the cyt $b$ and $12 \mathrm{~S}$ regions. Numbers above and below branches represent the posterior probabilities and ML bootstrap values, respectively. Black, dashed, and light grey branches identify samples from the mesomorphic, transitional, and hygromorphic zones, respectively.

Within clade A two nested clades are recovered (A1 and A2 in Fig. 4) with strong PP but weak MLB support. Clade A1 includes exclusively haplotypes from the mesomorphic zone $(\mathrm{MLB}=54, \mathrm{PP}=0.94)$, while clade A2 includes a mixture of haplotypes from the transitional zone (B10, B11, C11 and E11 areas), and haplotypes coming from the Central Valley + Andes in the southern mesomorphic zone $(\mathrm{F} 8, \mathrm{~F} 9$ and E9 areas; $\mathrm{MLB}=65, \mathrm{PP}=0.94)$. Within the transition zone, haplotypes from the Andean and Coastal ranges have not attained reciprocal monophyly. Within the clade A1, we recovered subclades consisting of haplotypes exclusive to the northern mesomorphic zone (G1, F2, E3, F5 and H4 areas), and those exclusive to the Coastal and Andean ranges in the central mesomorphic zone (G5, G7, F7, F8 and D8). This last node was strongly supported $(\mathrm{MLB}=83, \mathrm{PP}=1.0)$.

The gene tree for L. lemniscatus (Fig. 5) recovers two wellsupported clades; the smaller of these (clade A) includes three haplotypes from the area F5 and the northernmost haplotype from area F3, localities from the transverse 


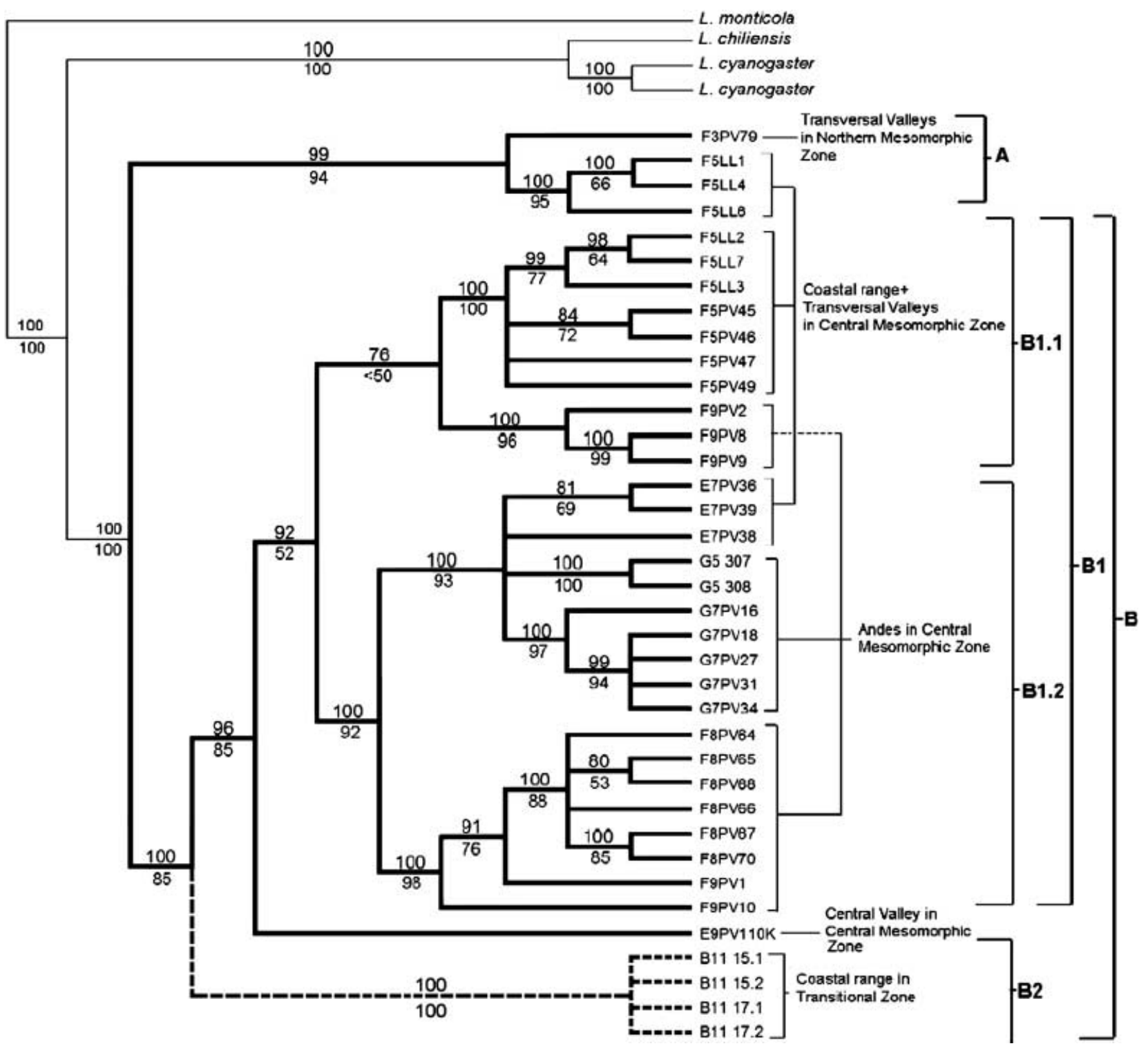

Fig. 5 Mitochondrial gene tree for Liolaemus lemniscatus based on ML $(\operatorname{lnL}=-6195.8893)$ and Bayesian analysis; numbers above and below branches, and branch shading are as found in Fig. 4.

valleys of the northern mesomorphic zone (MLB $=94$, $\mathrm{PP}=0.99$ ). The second clade (clade B; MLB $=85, \mathrm{PP}=1.0$ ) resolves two well-supported subclades that are reciprocally monophyletic with respect to geography. Clade B2 (MLB = $100, \mathrm{PP}=1.0)$ includes only haplotypes from the Coastal Range in the transitional zone (area B11). Clade B1 is well supported $(\mathrm{MLB}=85, \mathrm{PP}=0.96)$ and includes 29 unique haplotypes detected in this species, but none has sorted to monophyly by geographical locality. Subclade B1.1 (weakly supported) for example, includes haplotypes from the Coastal Range, transverse valleys, and the Andean Range in the central mesomorphic zone (areas F5 and F9). Similarly, subclade B1.2 (more strongly supported) is a mix of geographical areas: it includes haplotypes from the Coastal
Range, transverse valleys (both represented by area E7), and Andean Range (areas G5, G7, F8, and F9) of the central mesomorphic zone. Two well-supported haploclades within subclade B1.2 correspond to latitudinal regions previously recognized as distinct bioclimatic zones; one represents a northern subgroup restricted to an area between $34^{\circ} \mathrm{S}$ and $35^{\circ} \mathrm{S}$ latitude (E7, G5, G7), and the second includes haplotypes from areas $\mathrm{F} 8$ and $\mathrm{F9}$, approximately between $35^{\circ} \mathrm{S}$ and $36^{\circ} \mathrm{S}$ latitude. A unique haplotype from the Central Valley in the central mesomorphic zone is the sister to clade B1.

All analyses for $L$. pictus recover two highly divergent haploclades (A and B; Fig. 6). Clade A includes haplotypes from the Coastal Range, the Andean Range in the transitional zone, and more northern Andean areas from the hygro- 


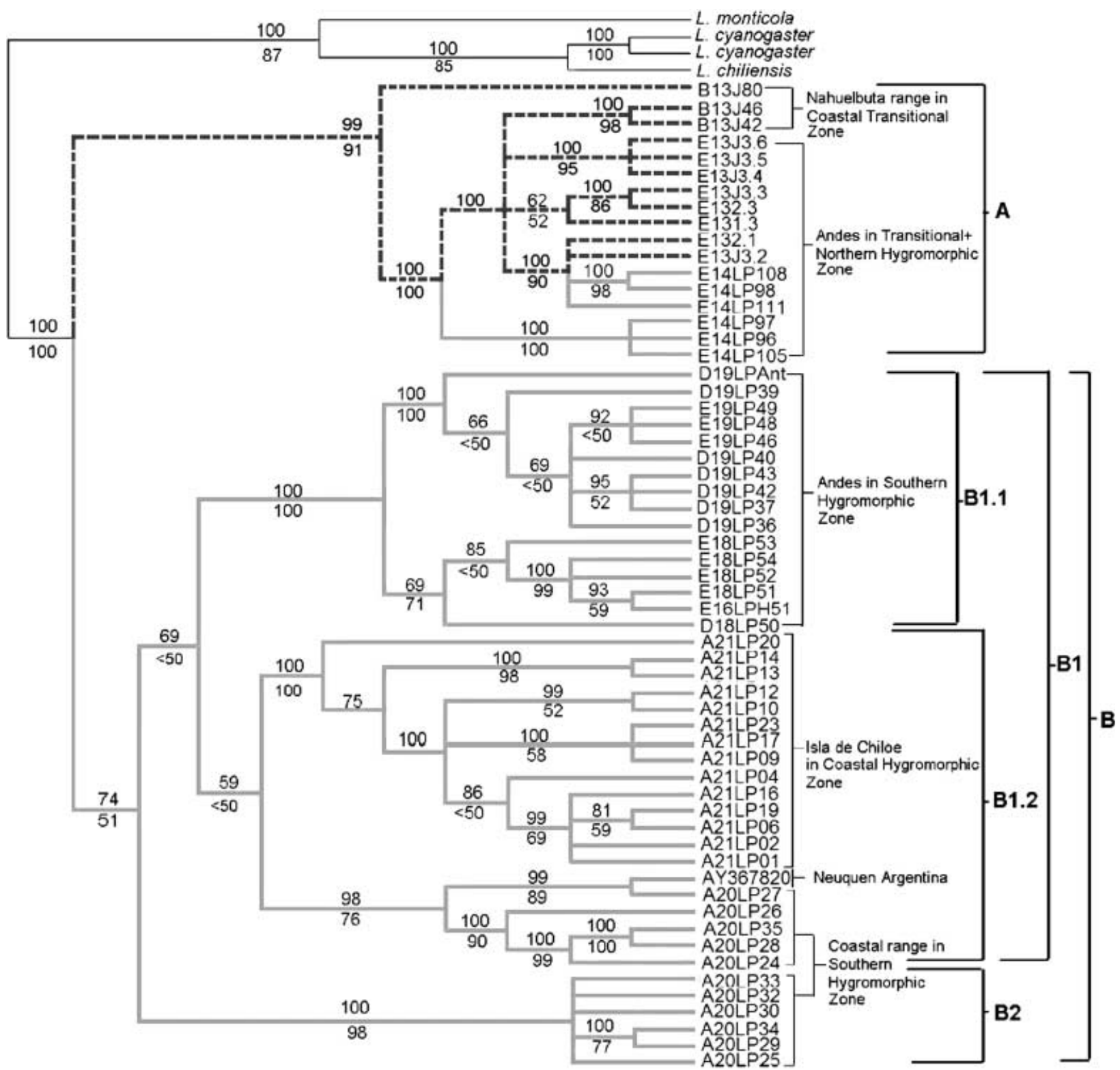

Fig. 6 Mitochondrial gene tree for Liolaemus pictus based in ML $(\operatorname{lnL}=-5816.3776)$ and Bayesian analysis; numbers above and below branches, and branch shading are as found in Figs 4 and 5 .

morphic zone, with strong support (MLB = 91, $\mathrm{PP}=0.99$ ). Clade B is comprised of haplotypes that are distributed exclusively in the hygromorphic zone, representing Andean and Coastal areas, albeit with weak support (MLB $=51$, $\mathrm{PP}=0.74)$. Within clade $\mathrm{B}$, six haplotypes from the mainland coastal area near Chiloé Island (A20; clade B2), are strongly supported as distinct from all other sequences in clade $B$ $(\mathrm{MLB}=98, \mathrm{PP}=1.0)$. The monophyly of clade B1 receives almost no support $(\mathrm{MLB}<50, \mathrm{PP}=0.69)$, but several of its subclades do. For example, clade B1.1 is comprised exclusively of Andean haplotypes from the southern hygromorphic zone (areas D18, D19, E16 and E18; Fig. 6;
MLB $=100, \mathrm{PP}=1.0$ ), and another includes all A21 haplotypes from Chiloé Island in the Coastal hygromorphic zone. Clade B1.1 is weakly recovered as the sister clade to a haploclade including the area A20 sequences from the coastal mainland adjacent to Chiloe Island, and the haplotype from Neuquen, Argentina.

\section{Comparative phylogeography}

The size of the three area trees (areas coded in Fig. 3) was 30 in L. tenuis, 11 in L. pictus and 10 in L. lemniscatus, for a total of 34 areas represented overall. There were no areas 


\begin{tabular}{llll}
\hline & Liolaemus tenuis & Liolaemus pictus & Liolaemus lemniscatus \\
\hline L. tenuis & $\ldots \ldots$ & $0.71(P<0.001)$ & $0.60(P<0.05)$ \\
L. pictus & 7 & $\ldots \ldots$ & $\ldots \ldots$. \\
L. lemniscatus & 10 & 0 & $\ldots \ldots$. \\
\hline
\end{tabular}

Table 3 Normalized MAST values (probability values in parentheses) of the randomization analysis (above diagonal); numbers below the diagonal are the number of shared areas in the sampling design

shared by all three species trees, but L. tenuis shared 10 localities with L. lemniscatus and seven with L. pictus; L. pictus and L. lemniscatus did not co-occur at any of our sampling locations. Plots of times to coalescence in units of genetic distance for correlated codivergence events were not significant. Table 3 summarizes standardized MAST scores for the two species pairs sampled from regions of overlap. The mean value for the two standardized MAST scores is 0.66; the comparison between L. tenuis and L. lemniscatus shows the higher value (0.71), and is highly significant by the randomization test $(P<0.001)$. The L. tenuis-L. pictus standardized MAST value is 0.60 , also significant $(P<0.05)$. The respective MAST for both comparisons are shown in Fig. 7(a,b). Both show a general trend of closely related haplotypes occupying proximal geographical areas. One exception is area D18 in the L. tenuis-L. pictus MAST, which is associated with the northern areas (B13 and E14). Because both comparisons gave significant $P$ values, we used them to generate a supertree representing the 34 sampled geographical regions.

The MRP tree obtained from the combination of the three individual area trees is shown in Fig. 7c, and summarizes the concordant phylogeographical associations of the species among the 34 areas sampled. This MRP tree was considered in the interpretation of the climatic variables analysed for three Chilean bioclimatic zones (mesomorphic, transitional and hygromorphic) defined by Mann (1964) and Pisano (1954). The MRP tree obtained from the Liolaemus haplotypes shows a topology clearly consistent with these a priori defined bioclimatic zones. One haploclade occupies many areas of the mesomorphic zone (root 1). Specifically, those from the northern and central areas constitute a clade (D8 to $\mathrm{H} 4$ ), latitudinally ranging from approximately $32^{\circ} \mathrm{S}$ to $35^{\circ} 30^{\prime} \mathrm{S}$. A second group includes areas from the southern mesomorphic zone (C9, E9, F9, E11) and some of those from the coastal transitional zone (B10, B11 and C11; root 2). The third group in the MRP tree includes all other areas from the transitional zone (Andean transitional zone, E12, B13 and E13), all areas from the hygromorphic zone, and the peripheral Argentinean site (root 3). The single geographical inconsistency detected is the association of the E7 area from mesomorphic zone within this third group, but in the topology of the MRP tree, this area is near the root of this group and close to the transitional areas in the second group.

The ANOSIM analysis of the climatic variables reveals highly significant differences among groups of geographical areas from the three bioclimatic zones (global $R=0.436$; $P<0.001$ ). Both comparisons involving the mesomorphic zone were statistically different; the mesomorphic-hygromorphic comparison showed $R=0.463(P<0.001)$, and the mesomorphic-transitional comparison gave $R=0.438$ $(P<0.05)$; there was no significant association for the hygromorphic-transitional comparison $(R=0.295 ; P>0.05)$. These results suggest more pronounced climatic differences between the mesomorphic and transitional zones than between the hygromorphic and transitional zones. Figure 8 presents the spatial arrangement of the 32 supertree geographical areas in an MDS three-dimensional plot representing a multivariate summary of the climatic variables. The stress value for MDS was low (0.03), corresponding to a good fit for this kind of analysis (i.e. little distortion between the original data and the scaling axes). The clusters of points in the graph are generally consistent with the latitudinal position of the localities, and consequently with the Chilean bioclimatic zones. The transitional points (squares) are clustered between the mesomorphic and hygromorphic zones, and the similarity patterns for the climatic variables among areas correspond to the genetic structure of the species phylogeographies represented in the supertree. Spearman rank correlations derived from the BIO-ENV routine indicated that five of the six weather parameters essentially captured the full MDS profile, and showed relatively high correlation values between the supertree distance matrix and the climate matrix (global $R=0.527$, $P<0.001$; Table 4).

\section{Discussion}

\section{General patterns of divergence}

We detected patterns of evolutionary relationships for each Liolaemus species that are consistent with Chilean geography. Independently, for the three Liolaemus species analysed, the topologies reflect latitudinal gradients. The general pattern for L. tenuis, the most broadly distributed, is a higher genetic diversity, longer branch lengths and greater population structure in the mesomorphic zone, while the opposite is observed for the periglacial and glacial populations. Liolaemus lemniscatus is mainly distributed in the Mesomorphic zone and its level of divergence between haplotypes suggests a similar history to the northern codistributed area of Liolaemus tenuis. Clades of both species show a general 
(a)

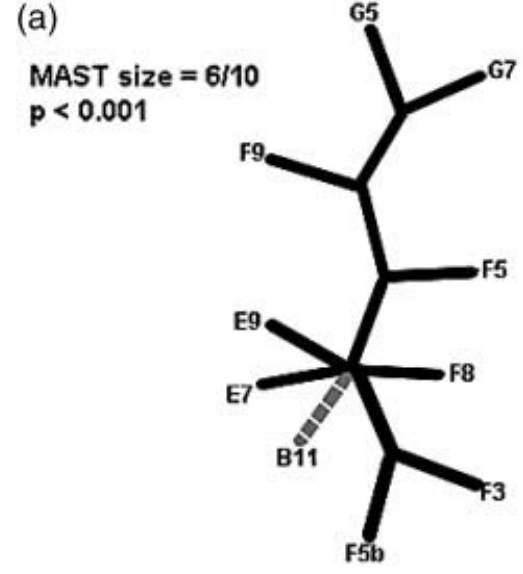

(b)

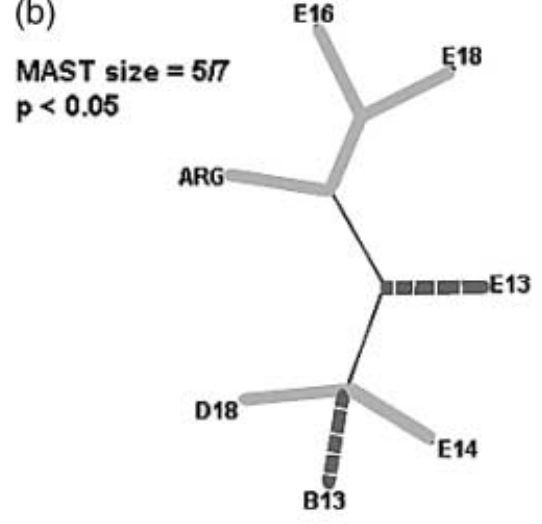

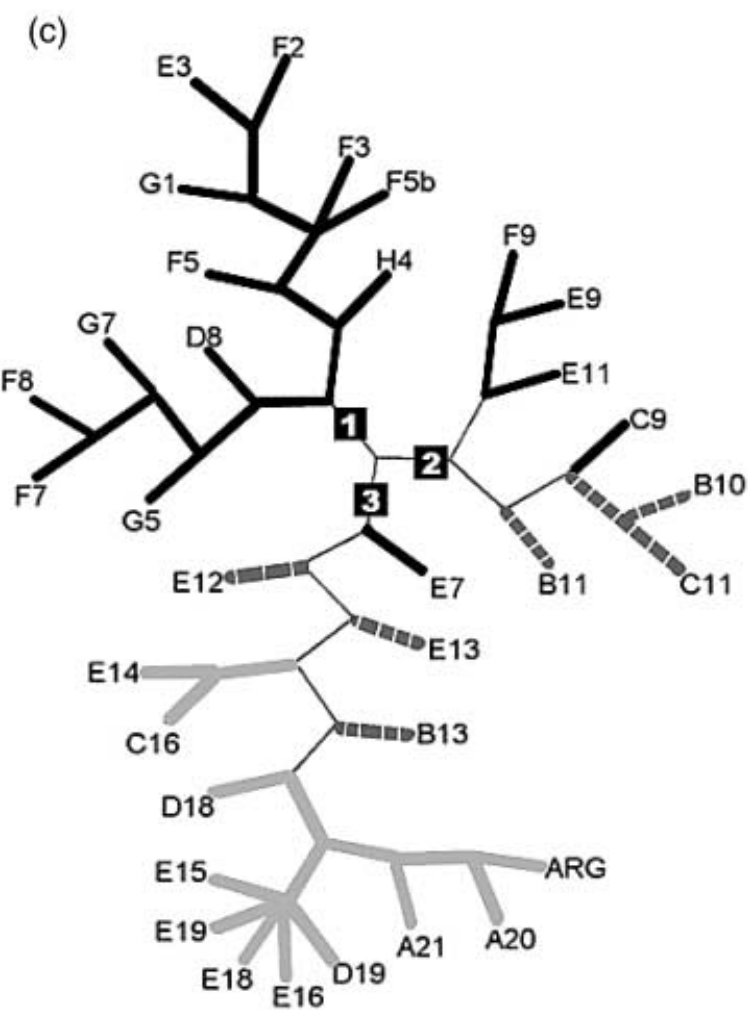

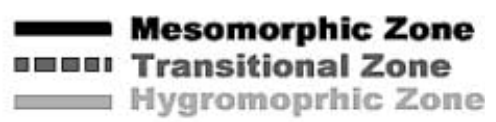

Fig. 7 MAST for pairwise combinations of area trees between Liolaemus tenuis-Liolaemus lemniscatus (a), and L. tenuis-Liolaemus pictus (b). $\mathrm{C}$ presents the MRP tree obtained from the combination of the three individual area trees; area codes are as described in Table 1 . The main clades are labelled with numbers from 1 to 3, and branch shading is as found in Figs 4-6.

pattern of higher gene and/or nucleotide diversity in northern (A clades) vs. southern (B clades) localities (Table 2). Finally, Liolaemus pictus, the most southern species, is characterized by diversity and branch lengths that are curiously higher than the codistributed populations of L. tenuis. The southernmost populations of L. pictus, which are definitively distributed in glaciated areas, are characterized by branch lengths and genetic diversity indexes consistent with a reduced effect of glacial cycles on patterns of genetic variation. All this suggests a complex history that requires additional corroborative evidence for resolution, but broadly similar patterns - deep phylogeographical structure in northern populations and high genetic similarity on both sides of the Andes in southern populations - have been reported in two other terrestrial species; the conifer Fitzroya cupressoides (Allnut et al. 1999), and forest-dwelling rodents of the Abrothrix olivaceous/xanthorinus complex (Smith et al. 2001), and in the freshwater fish Percichthys trucha (Ruzzante et al. 2006).
Our gene tree for $L$. tenuis recovered a close relationship between the eastern Argentinean populations of and southern Chilean populations from the Continental Chiloé (clade B; Fig. 3), where it is probable that several low elevation gaps connected biota from both sides of the Andes at these latitudes. Similarly, within the fish P. trucha, deep mtDNA haplotype divergence between western vs. eastern drainages is evident in northern regions $\left(38^{\circ}\right)$, presumably because of a history dominated by vicariant events in this part of the range. Further south, $P$. trucha is characterized by the absence of deep divergence between eastern and western populations, and at approximately $40^{\circ} \mathrm{S}$ several western drainages include haplotypes that are more closely related to some eastern-drainage haplotypes than they are to those in other western populations. Ruzzante et al. (2006) interpreted this pattern as possibly due to historical gene flow followed by a recent cessation of former trans-Andean watershed connections in southern regions. In contrast, genetic patterns in northern populations of 
3D Stress: 0.03

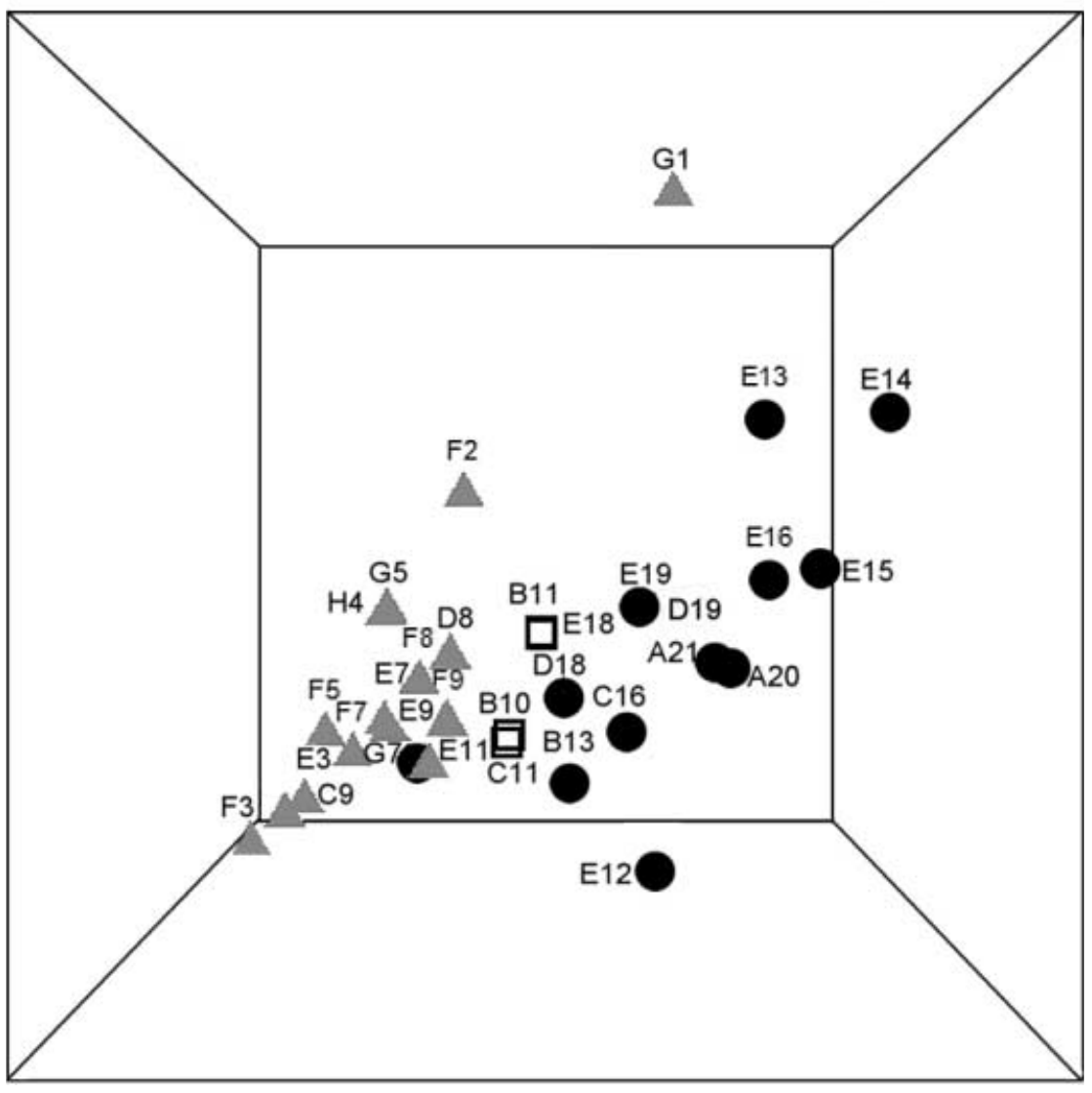

Fig. 8 Multidimensional scaling analysis summarizing six climate variables (see text for details) for the three Chilean biogeographical zones. Triangles, mesomorphic zone; squares, transitional zone; and circles, hygromorphic zone; area codes are as described in Table 1.
Table 4 Spearman rank correlations (PRIMER version 6 BIO-ENV) between areas supertree distances and weather variables based distances. Variables: (1) $T$, annual mean temperature; (2) $M$, mean daily maximum temperature of the coldest month; (3) $m$, mean daily minimum temperature of the coldest month; (4) $I_{\mathrm{C}^{\prime}}$ index of continentality or thermal amplitude (calculated as the difference between the daily mean temperatures of the hottest and coldest months); (5) $P$, mean annual precipitation

\begin{tabular}{lll}
\hline Number of variables & Correlation & Selections \\
\hline 2 & 0.527 & 1,5 \\
2 & 0.527 & 2,5 \\
3 & 0.527 & $1,2,5$ \\
3 & 0.527 & $1,4,5$ \\
3 & 0.527 & $2,4,5$ \\
3 & 0.527 & $3,4,5$ \\
4 & 0.527 & $1,2,4,5$ \\
4 & 0.527 & $1,3,4,5$ \\
4 & 0.527 & $2,3,4,5$ \\
5 & 0.527 & $1,2,3,4,5$ \\
\hline
\end{tabular}

P. trucha suggest relatively stable habitats and limited dispersal (Ruzzante et al. 2006), and this pattern is broadly replicated in two of the three species of Liolaemus in this study.

\section{Comparative phylogeography}

Our results are consistent with the hypothesis that two paired combinations of three species of Liolaemus included in this study have responded in parallel to shared historical process sufficient to influence their phylogeographical structure. In other words, these species (L. tenuis, L. lemniscatus) have been codistributed for a sufficiently long time to possibly have evolved along similar demographic trajectories in response to the same historical events. Among other things, natural selection and/or vicariant events associated with recent cycles of glaciation (Heusser 1981; van Geel et al. 2000) and floral changes associated with shifting climates (Villagrán \& Hinojosa 1997), may have driven parallel divergence in these lizards. The genetic and geographical structure of the populations described by the area supertree is consistent with this hypothesis.

In the northern range of the Liolaemus species studied here (mesomorphic zone), our results show significant phylogeographical congruence between L. lemniscatus and L. tenuis. Because this region should have been less directly impacted by late Pleistocene glaciation cycles (McCulloch et al. 2000), and because both of these species show deep phylogeographical structure in this region relative to more southern parts of their ranges, we suggest that older tectonic/ 
orogenic events, or perhaps very old climatic events (onset of Pleistocene changes) may have most strongly influenced the histories of each species. Specifically, the occurrence of a complex mix of localized transverse valleys bisected by high mountains, and the complete isolation of the Andean and Coastal ranges, coupled with less dramatic climatic oscillations resulting from cycles of glacial advance/retreat further south (Hollin \& Schilling 1981), may have forged deep phylogeographical splits and allowed the persistence of old haplotypes at some localities. These northern populations segregate for both old and newer (derived) haplotypes (especially L. tenuis) relative to more southern populations.

The second significant comparison of this study includes more southern populations of $L$. tenuis and its overlap in part with L. pictus; heterospecific populations in this region may have shared a history of unstable and recurrent changes associated with repeated younger Pleistocene glaciations. Three or four glacial events are recorded from this region, all of which strongly influenced vegetation dynamics (e.g. Pastorino \& Gallo 2002), and probably influenced microevolutionary processes in most of the associated biota. These glacial cycles operated for approximately 2 million years during the Pleistocene, from which the LGM began 20 000-18 000 bp and finished 14000 $10000 \mathrm{bp}$. During the LGM, the ice sheet was about $2000 \mathrm{~km}$ long and followed the distribution of the Andes range, from $34^{\circ} \mathrm{S}$ to $56^{\circ} \mathrm{S}$ (Fig. 1). At its maximum extent, the ice sheet extended from sea level at $43^{\circ} \mathrm{S}$ (Hollin \& Schilling 1981), and to the north the ice sheet's influence extended to the approximate latitude of Santiago, where it descended to $500 \mathrm{~m}$ (Solbrig 1976). This climatic/geological scenario is consistent with the levels of divergence and genetic variation detected for one of the two species distributed in southern Chile. Specifically L. tenuis, the most widely distributed species sampled, showed lower values both for the haplotype and nucleotide diversity for the clade distributed from $38^{\circ} \mathrm{S}$ to the southern edge of its distribution (Clade B; Fig. 4). This clade was characterized by the shortest branch lengths of all terminals (tree not shown), and by a few and very similar haplotypes distributed across a broad area that was strongly influenced by the ice shield. We hypothesize that this signature reflects a relatively recent range expansion at these latitudes after the retreat of the ice shield.

All data suggest that the climate was colder and more humid than at present during glacial advances, and that this influence was strongest in the southern region and decreased in effect from south-to-north to the transitional zone (Villagrán 2001). The general model for changes in the biotic distributions during these glacial-postglacial cycles suggests that glacial effects led to local extinctions, fragmentation, isolation, and rearrangements in assemblages of species, forcing many taxa into refugia in the north, northwest, or in the east in the Patagonian Steppe

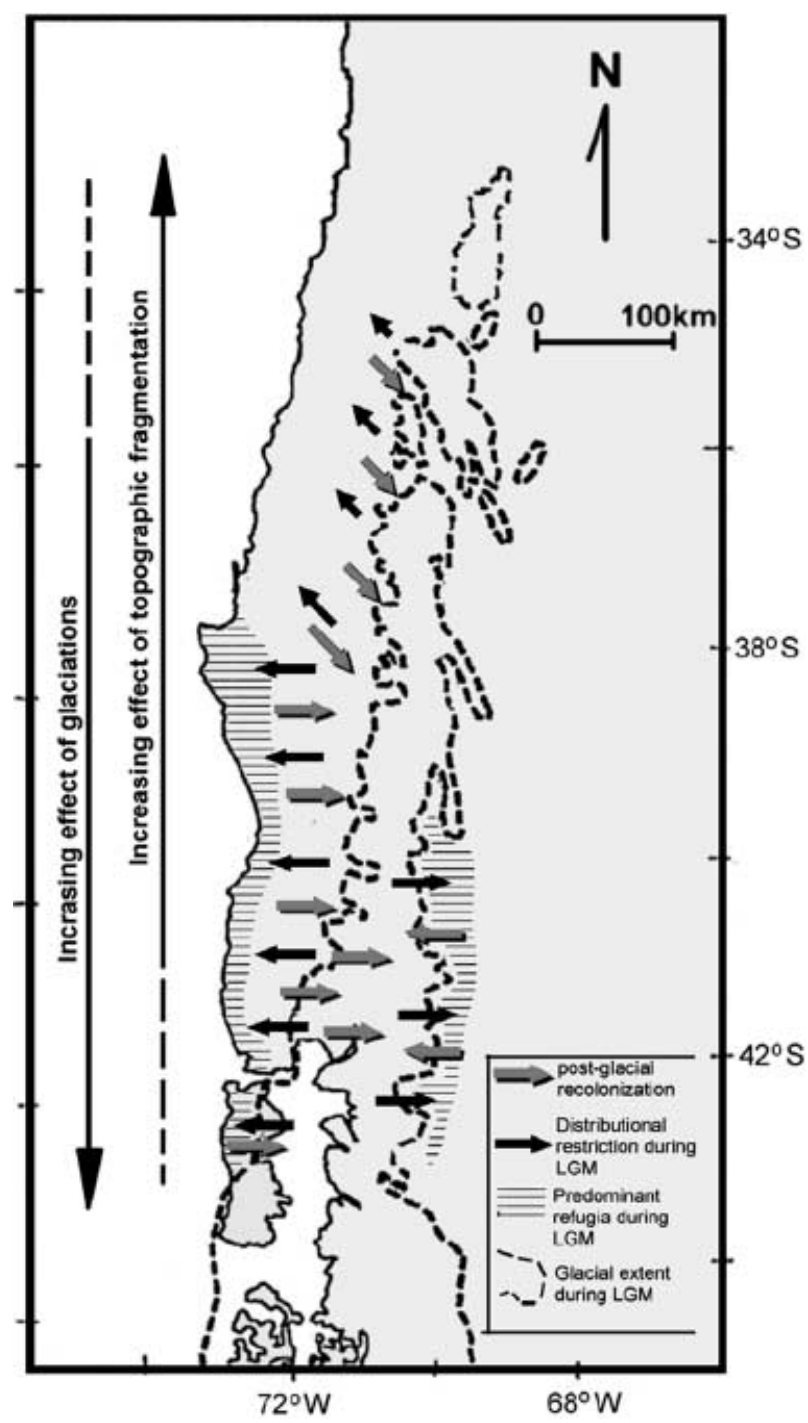

Fig. 9 Distribution of major refugial areas postulated for the LGM, and generalized dispersal routes postulated for the three species of Liolaemus considered in this study.

(Muellner et al. 2005). Recent evidence for low-elevation Pleistocene refugia was presented by Premoli et al. (2000, 2003), who suggested that a great part of the Chilean Patagonian biota was likely pushed into coastal areas between $38^{\circ} \mathrm{S}$ and $43^{\circ} \mathrm{S}$ (Fig. 9). As one example, the Andean Nothofagus forest was likely pushed north and from high to low altitudes with glacial advances, and it has only recently colonized the central valleys (Villagrán \& Hinojosa 1997; Villagrán 2001).

The demonstration of spatially congruent evolutionary histories shared among two combinations of the Liolaemus species studied here implies a sufficiently long ecological association between these taxa (in parts of their ranges) for tectonic and/or climatic factors to generate congruent phylogeographical patterns. We are encouraged by these 
results, because this study is a very broad assessment of patterns across a topographically and climatically extremely variable landscape, and it ignores the fact that, even for congeners, there are sufficient life-history differences among the Liolaemus species studied here to confound phylogeographical patterns at finer scales of resolution. For example, the effect of colder climatic conditions in southern Chile must be a significant factor in causing extinctions or density reductions in local populations of ectothermal terrestrial vertebrates in general. While the effects of glaciations in southern populations of L. tenuis and L. pictus should result in a shared phylogeographical pattern in this region, important differences between the two are almost certainly responsible for the more complex patterns in this part of the range. Liolaemus tenuis has a broader distribution than L. pictus, and the former generally occupies more open habitats and forest edges, while L. pictus is more strongly associated with forest habitat. This difference alone suggests that $L$. tenuis likely has higher thermal requirements, and it is also oviparous whereas L. pictus is viviparous, which would also favour L. pictus in cooler environments. Our study was not designed to distinguish among such variables to make inferences about ecological factors that might explain divergence, or absence thereof, within and between species in this group, and we mention these here simply to recognize the limits of this study.

The most powerful property of comparative phylogeography is the use of information from different codistributed clades - ideally with very different ecologies - presumed to share a history of similar climatic and geological processes; these represent independent replications in a natural experiment of evolution (Zink 2002; Zamudio \& Savage 2003). Many studies have analysed the comparative phylogeography of codistributed taxa from independent lineages, with the aim of detecting common evolutionary processes, but until recently the most common approach consisted of qualitative and visual comparisons of individual gene trees (Avise 2000). More recently statistical methods have been used to quantitatively test alternative $a$ priori hypotheses of congruence in phylogeographical patterns of sympatric taxa (e.g. Carstens et al. 2005), but these approaches are problematic in taxa with only partially overlapping distributions. A major advantage of the method used here (Lapointe \& Rissler 2005) is that MRP trees can be compared in paired statistical tests appropriate to species sharing partially overlapping ranges.

This is the first comparative phylogeographical study in southern South America using statistical methods to test for the occurrence of areas with common evolutionary history, but much remains to be done in follow-up studies. For example, our analysis of climate variables suggests that the previously defined bioclimatic zones have some explanatory power for natural selection to drive population divergence, but more detailed niche modelling efforts will need to be integrated with geographical range information for stronger inferences on the role of habitat differences in driving speciation (Graham et al. 2004). More intensive sampling will provide more details on potential areas of overlap which can be evaluated with additional new tests of shared history (Zhang et al. 2006), and these can be linked to expanded genetic studies with nuclear markers to test long-term demographic stability that might be expected in refugial areas (Hutchinson \& Templeton 1999; Knowles \& Richards 2005). Finally, tests for codivergence in space must be linked to tests for codivergence in time (Hickerson et al. 2006); such studies in this part of the world will provide a southern hemisphere perspective to the comparative phylogeographical studies of the effects of Quaternary glacial cycles in Europe and North America (Hewitt 2000; Moreno et al. 2001). The approach will also yield more general patterns with the inclusion of more taxa, and these studies are in progress.

\section{Acknowledgements}

We thank the following people for help in the field or in the laboratory - M. Vidal, E. Habit, M. Fernandez, R. Cifuentes, J. Bourke (all of Universidad de Concepción: Chile), F. Torres (Pontificia Universidad Católica de Chile), the Victoriano-Sepúlveda and CisternasOjeda families; J. Alsbury and M. Hawkins (Brigham Young University); E. Habit (UdeC) assisted with part of the statistical analysis of weather data. Logistic and financial support was provided by Brigham Young University (David M. Kennedy Center for International Studies, and the Department of Integrative Biology, M.L. Bean Life Science Museum). The project was also financially supported in part by the US Department of Agriculture (award CSREES NRI 2005-00903 to BJA), US National Science Foundation (awards DEB 0132227 and OISE 0530267 to J.W.S., Jr. and others, DEB 0309111 to J.W.S., Jr. and E.B.; and award DEB 0640959 to B.J.A.), and Beca Presidente de la República (Mideplan, Chile) and Project DIUC-CIEP 205.113.067-1sp, Universidad de Concepción.

\section{References}

Allnut TR, Newton AC, Lara A et al. (1999) Genetic variation in Fitzroya cupressoides (alerce), a threatened South American conifer. Molecular Ecology, 8, 975-987.

Amigo J, Ramírez C (1998) A bioclimatic classification of Chile: woodland communities in the temperate Zone. Plant Ecology, 136, 9-26.

Arbogast BS, Kenagy GJ (2001) Comparative phylogeography as an integrative approach to historical biogeography. Journal of Biogeography, 28, 819-825.

Avila LJ, Morando M, Perez CHF, Sites JW Jr (2004) Phylogenetic relationships of lizards of the Liolaemus petrophilus group (Squamata, Liolaemidae), with description of two new species from western Argentina. Herpetologica, 60, 187-203.

Avila LJ, Morando M, Sites JW Jr (2006) Congeneric phylogeography: hypothesizing species boundaries and evolutionary processes in lizards of the Liolaemus boulengeri complex (Squamata: Liolaemini). Biological Journal of the Linnean Society, 89, 241-275. 
Avise JC (2000) The History and Formation of Species. Harvard University Press, Cambridge, Massachusetts.

Bermingham E, Moritz C (1998) Comparative phylogeography: concepts and applications. Molecular Ecology, 7, 367-369.

Bininda-Emonds ORP (2004) The evolution of supertrees. Trends in Ecology \& Evolution, 19, 315-322.

Carstens BC, Knowles LL (2007) Shifting distributions and speciation: species divergence during rapid climate change. Molecular Ecology, 16, 619-627.

Carstens BC, Richards CL (2007) Integrating coalescent and ecological niche modeling in comparative phylogeography. Evolution, 61, 1439-1454.

Carstens BC, Brunsfeld SJ, Demboski JR, Good JM, Sullivan J (2005) Investigating the evolutionary history of the Pacific northwest mesic forest ecosystem: hypothesis testing within a comparative phylogeographic framework. Evolution, 59, 1639-1652.

Cei JM, Videla F, Vicente L (2003) From oviparity to viviparity: a preliminary note on the morphometric differentiation between oviparous and viviparous species assigned to the genus Liolaemus (Reptilia, Squamata, Liolaemidae). Journal of Zoological Systematics and Evolutionary Researches, 41, 151-156.

Clarke KR (1999) Non-metric multivariate analysis in communitylevel ecotoxicology. Environmental Toxicology and Chemistry, 18, 117-127.

Clarke KR, Gorley RN (2005) PRIMER v.6: User Manual/Tutorial. PRIMER-E Ltda., Plymouth, UK.

Di Castri F (1968) Esquisse écologique du Chili. In: Biologie de l'Amérique austral (eds Delamare Deboutteville, C, Rapoport T), pp. 7-52. Edition du Centre National de la Recherche Scientifique, Paris, France.

Donoghue MJ, Moore BR (2003) Toward an integrative historical biogeography. Integrative and Comparative Biology, 43, 261-270.

Donoso-Barros R (1966) Reptiles de Chile. Ediciones de la Universidad de Chile, Santiago, Chile.

Duméril AMC, Bibron G (1837) Erpétologie générale ou histoire naturelle del Reptiles. Vol 8. Imprimerie Paris De Fain, Paris.

Fetzner J (1999) Extracting high quality DNA from shed reptiles skins; A simplified method. BioTechniques, 26, 1052-1054.

van Geel B, Heusser C, Renssen H, Schuurmans JE (2000) Climatic change in Chile at around $2700 \mathrm{BP}$ and global evidence for solar forcing: a hypothesis. Holocene, 10, 659-664.

Graham CH, Ferrier S, Huettman F, Moritz C, Peterson AT (2004) New developments in museum-based informatics and applications in biodiversity analyses. Trends in Ecology \& Evolution, 19, 497-503.

Gravenhorst JLC (1838) Beitrage zur genauern Kenntnis einiger Eidechsengattungen. Nova Acta Academiae Caesarae Leopoldina Carolinae Germaninicae Naturae Curisorum, 18, 712-784.

Heusser C (1981) Palynology of the last interglacial-glacial cycle in midlatitudes of southern Chile. Quaternary Researches, 16, 293-321.

Hewitt G (2000) The genetic legacy of the Quaternary ice ages. Nature, 405, 907-913.

Hickerson MJ, Dolman G, Moritz C (2006) Comparative phylogeography summary statistics for testing simultaneous vicariance. Molecular Ecolology, 15, 209-223.

Hillis DM, Bull JJ (1993) An empirical test of bootstrapping as a method for assessing confidence in phylogenetic analysis. Systematic Biology, 42, 182-192.

Hollin JTS, Schilling DH (1981) Late Wisconsin-Wichselian mountain glaciers and small ice caps. In: The Last Great Ice Sheets (eds Denton JH, Hughes TJ), pp. 179-206. Wiley, New York.
Huelsenbeck JP, Bollback JP (2001) Empirical and hierarchical Bayesian estimation of ancestral status. Systematic Biology, 50, 351-366.

Huelsenbeck JP, Ronquist F (2001) MRBAYEs. Bayesian inference of phylogeny. Bioinformatics, 17, 754.

Hugall A, Moritz C, Moussalli A, Stanisic J (2002) Reconciling paleodistribution models and comparative phylogeography in the Wet Tropics rainforest land snail Gnarosophia bellendenkerensis (Brazier 1875). Proceedings of the National Academy of Sciences, USA, 99, 6112-6117.

Hutchinson DW, Templeton AR (1999) Correlation of pairwise genetic and geographic distance measures: inferring the relative influences of gene flow and drift on the distribution of genetic variability. Evolution, 53, 1898-1914.

Johnson JB, Omland KS (2004) Model selection in ecology and evolution. Trends in Ecology \& Evolution, 19, 101-108.

Knowles LL, Richards CL (2005) Genetic drifts importance during Pleistocene divergence as revealed by analysis of genomic variation. Molecular Ecology, 14, 4023-4032.

Lamborot M, Ortiz JC (1990) Liolaemus pseudolemniscatus, una nueva especie de lagarto del Norte Chico de Chile (Sauria: Tropiduridae). Gayana, 54, 135-142.

Lapointe F, Rissler L (2005) Congruence, consensus and the comparative phylogeography of codistributed species in California. American Naturalist, 166, 290-299.

Leaché AD, Reeder TW (2002) Molecular systematics of the eastern fence lizard (Sceloporus undulatus): a comparison of parsimony, likelihood, and Bayesian approaches. Systematic Biology, 51, $44-68$.

Lowell TV, Heusser CJ, Andersen BG et al. (1995) Interhemispheric correlations of Late Pleistocene glacial events. Science, 269, 1541-1549.

Mann G (1964) Regiones Biogeográficas de Chile. Investigaciones Zoológicas Chilenas, VI, 15-49.

Martins EP, Labra A, Halloy M, Thompson JT (2004) Largescale patterns of signal evolution: an interspecific study of Liolaemus lizard headbob displays. Animal Behaviour, 68, 453-463.

McCulloch RD, Bentley MJ, Purves RS, Hulton NRJ, Sugden DE, Clapperton CM (2000) Climatic inferences from glacial and palaeoecological evidence at the last glacial termination, southern South America. Journal of Quaternary Science, 15, 409-417.

Morando M, Avila LJ, Sites JW Jr (2003) Sampling strategies for delimiting species: genes, individuals, and populations in the Liolaemus elongates-kriegi complex (Squamata: Liolaemidae) in Andean-Patagonian South America. Systematic Biology, 52, 159-185.

Morando M, Avila LJ, Baker J, Sites JW Jr (2004) Phylogeny and phylogeography of the Liolaemus darwinii complex (Squamata: Liolaemidae): evidence for introgression and incomplete lineage sorting. Evolution, 58, 842-861.

Morando M, Avila LJ, Turner C, Sites JW Jr (2007) Molecular evidence for a species complex in the Patagonian lizard Liolaemus bibroni and phylogeography of the closely related L. gracilis (Squamata: Liolaemini). Molecular Phylogenetics and Evolution, 43, 952-973.

Moreno PI, Jacobson GL, Lowell TV, Denton GH (2001) Interhemispheric climate links revealed from a Late-glacial cool episode in southern Chile. Nature, 409, 804-808.

Moritz C (2002) Strategies to protect biological diversity and the processes that sustain it. Systematic Biology, 51, 238-254.

Muellner AN, Tremetsberger K, Stuessy T, Baeza CM (2005) Pleistocene refugia and recolonization routes in the southern 
Andes: insights from Hypochaeris palustris (Asteraceae, Lactuceae). Molecular Ecology, 14, 203-212.

Nei M (1987) Molecular Evolutionary Genetics. Columbia University Press, New York.

Nuñez H, Jaksic F (1992) Lista comentada de los reptiles terrestres de Chile continental. Boletin Del Museo Nacional de Historia Natural (Chile), 43, 63-91.

Page RDM (1994) Parallel phylogenies: reconstructing the history of host-parasite assemblages. Cladistics, 10, 155-173.

Palumbi SR (1996) Nucleic acids I: the polymerase chain reaction. In: Molecular Systematics (eds Hillis DM, Moritz C, Mable BK), 2nd edn, pp. 205-247. Sinauer \& Associates, Sunderland, Massachusetts.

Pastorino MJ, Gallo LA (2002) Quaternary evolutionary history of Austrocedrus chilensis, a cypress native to the Andean-Patagonian forest. Journal of Biogeography, 29, 1167-1178.

Pincheira-Donoso D, NunezNúñez H (2005) Las especies del genero Liolaemus Wiegmann, 1834 (Iguania: Tropiduridae: Liolaeminae). Taxonomía, sistemática y evolución. Publicación Ocasional del Museo de Historia Natural. Chile, 59, 7-486.

Pisano E (1954) Fitogeografía. La vegetación de las distintas zonas geográficas chilenas. Revista Geographyráfica de Chile Terra Australis, 11, 95-107.

Posada D, Buckley TR (2004) Model selection and model averaging in phylogenetics: advantages of Akaike information criterion and Bayesian approaches over likelihood ratio tests. Systematic Biology, 53, 793-808.

Posada D, Crandall KA (1998) MODELTEST: testing the model of DNA substitution. Bioinformatics, 14, 817-818.

Premoli AC, Kitzberger T, Veblen TT (2000) Isozyme variation and recent biogeographical history of the long-lived conifer Fitzroya cupressoides. Journal of Biogeography, 27, 251-260.

Premoli AC, Vergara R, Souto CP, Lara A, Newton AC (2003) Lowland valleys shelter the ancient conifer Fitzroya cupressoides in the Central Depression of Southern Chile. Journal of the Royal Society of New Zealand, 33, 623-631.

Ramos VA (1989) The birth of southern South America. American Scientist, 77, 444-450.

Rissler LJ, Hijmans RJ, Graham CH, Moritz C, Wake DB (2006) Phylogeographic lineages and species comparisons in conservation analyses: a case study of the California herpetofauna. American Naturalist, 167, 655-666.

Ruzzante D, Walde S, Cussac V et al. (2006) Phylogeography of the Percichthyidae (Pisces) in Patagonia: roles of orogeny, glaciation, and volcanism. Molecular Ecology, 15, 2949-2968.

Schulte II JA, Macey JR, Espinoza RE, Larson A (2000) Phylogenetic relationships in the iguanid lizard genus Liolaemus: multiple origins of viviparous reproduction and evidence for recurring Andean vicariance and dispersal. Biological Journal of the Linnean Society, 69, 75-120.

Smith MF, Kelt DA, Patton JL (2001) Testing models of diversification in mice in the Abrothrix olivaceus/xanthorhinus complex in Chile and Argentina. Molecular Ecology, 10, 397-405.

Smith-Ramirez C (2004) The Chilean coastal range: a vanishing center of biodiversity and endemism in South America temperate rainforest. Biodiversity and Conservation, 13, 373393.

Solbrig O (1976) The Origin and floristic affinities of the South American temperate desert and semidesert. In: Evolution of Desert Biota (eds Goodall DW), pp. 7-49. University Texas Press, Austin. Swofford CL (2002) PAUP*: Phylogenetic Analysis Using Parsimony
( ${ }^{*}$ and Other Methods), Beta Version 4.0.b5b. Sinauer \& Associates, Sunderland, Massachusetts.

Thompson JD, Gibson TJ, Plewniak F, Jeanmougin F, Higgins DG (1997) The ClustaL-windows interface: flexible strategies for multiple sequence alignment aided by quality analysis tools. Nucleic Acids Researches, 24, 4876-4882.

Thorley JL, Page RDM (2000) RADCon: phylogenetic comparison and consensus. Bioinformatics, 16, 486-487.

Vidal M, Ortiz JC, Astorga M, Victoriano P, Lamborot M (2004) Revision of Liolaemus tenuis subspecies (Duméril \& Bibron, 1837) by analysis of population genetic structure. Amphibia-Reptilia, 25, 438-445.

Vidal M, Ortiz JC, Ramírez CC, Lamborot M (2005a) Intraspecific variation in morphology and sexual dimorphism in Liolaemus tenuis (Tropiduridae). Amphibia-Reptilia, 26, 343-351.

Vidal M, Veloso A, Mendez M (2005b) Insular morphological divergence in the lizard Liolaemus pictus (Liolaemidae). AmphibiaReptilia, 27, 103-111.

Villagrán C (2001) Un modelo de la historia de la vegetación de la Cordillera de la Costa central-sur: la hipótesis glacial de Darwin. Revista Chilena de Historia Natural, 74, 793-803.

Villagrán C, Hinojosa LF (1997) Historia de los bosques del sur de Sudamérica, II: análisis fitogeográfico. Revista Chilena de Historia Natural, 70, 241-267.

Wiens JJ (1998) Combining data sets with different phylogenetic histories. Systematic Biology, 47, 568-581.

Wiens JJ, Reeder TW, Nieto Montes de Oca A (1999) Molecular phylogenetics and evolution of sexual dichromatism among populations of the Yarrow's spiny lizards (Sceloporus jarrovii). Evolution, 53, 1884-1897.

Wilkinson M, Cotton JA, Creevey C et al. (2005) The shape of supertrees to come: tree shape related properties of fourteen supertree methods. Systematic Biology, 54, 419-431.

Yang Z (1994) Estimating the pattern of nucleotide substitution. Journal of Molecular Evolution, 39, 105-111.

Zamudio KR, Savage WK (2003) Historical isolation, range expansion, and secondary contact of two highly divergent mitochondrial lineages in spotted salamanders (Ambystoma maculatum). Evolution, 57, 1631-1652.

Zhang AB, Tan S, Sota T (2006) AUTOINFER1.0: a computer program to infer biogeographical events automatically. Molecular Ecology Notes, 6, 597-599.

Zink RM (2002) Methods in comparative phylogeography, and their application to studying evolution in the North American aridlands. Integrative Comparative Biology, 42, 953-959.

Pedro F. Victoriano is an Associate Professor of Vertebrate Biology at Universidad de Concepción with interest in microevolution, ecology and comparative phylogeography. Juan Carlos Ortiz is a Professor of Zoology at Universidad de Concepción with interest in taxonomy and evolution of amphibian and reptiles. Edgar Benavides performed this research at Brigham Young University (BYU) while a PhD student and a post-doctoral researcher; his interests are evolutionary and population genetics, systematics, taxonomy, and conservation of Neotropical amphibians and reptiles. Jack W. Sites, Jr. is a professor of Biology and Curator of Herpetology at BYU, and he has similar interests. Byron Adams is an Assistant Professor of Microbiology and Molecular Biology at BYU with interests in coevolution and comparative phylogeography. 
20 P. F. VICTORIANO ET AL.

\section{Appendix}

Haplotype (gene) diversity/nucleotide diversity $(\pi)( \pm \mathrm{SD})$, for each analysed area, and total values for the three species of Liolaemus. $\mathrm{n} / \mathrm{c}$, values not calculated

\begin{tabular}{|c|c|c|c|}
\hline Area & L. lemniscatus & L. tenuis & L. pictus \\
\hline $1 G$ & & $0.667 \pm 0.314 / 0.001 \pm 0.001$ & \\
\hline $2 \mathrm{~F}$ & & $0.833 \pm 0.222 / 0.012 \pm 0.003$ & \\
\hline $3 \mathrm{E}$ & & $0.700 \pm 0.218 / 0.017 \pm 0.003$ & \\
\hline $3 \mathrm{~F}$ & $\mathrm{n} / \mathrm{c}$ & $0.607 \pm 0.164 / 0.003 \pm 0.001$ & \\
\hline $4 \mathrm{H}$ & & $\mathrm{n} / \mathrm{c}$ & \\
\hline $5 \mathrm{~F}$ & $0.982 \pm 0.046 / 0.059 \pm 0.007$ & $0.714 \pm 0.181 / 0.009 \pm 0.002$ & \\
\hline $5 G$ & $1.000 \pm 0.500 / 0.008 \pm 0.003$ & $0.500 \pm 0.265 / 0.003 \pm 0.001$ & \\
\hline $7 \mathrm{E}$ & $0.833 \pm 0.222 / 0.007 \pm 0.002$ & $0.600 \pm 0.175 / 0.003 \pm 0.001$ & \\
\hline $7 \mathrm{~F}$ & & $0.000 \pm 0.000 / 0.000 \pm 0.000$ & \\
\hline $7 \mathrm{G}$ & $0.867 \pm 0.071 / 0.005 \pm 0.001$ & $0.750 \pm 0.139 / 0.002 \pm 0.001$ & \\
\hline $8 \mathrm{D}$ & & $1.000 \pm 0.500 / 0.005 \pm 0.003$ & \\
\hline $8 \mathrm{~F}$ & $0.929 \pm 0.084 / 0.004 \pm 0.001$ & $1.000 \pm 0.126 / 0.036 \pm 0.005$ & \\
\hline $9 \mathrm{C}$ & & $0.000 \pm 0.000 / 0.000 \pm 0.000$ & \\
\hline $9 \mathrm{E}$ & $\mathrm{n} / \mathrm{c}$ & $0.864 \pm 0.072 / 0.004 \pm 0.001$ & \\
\hline $9 \mathrm{~F}$ & $1.000 \pm 0.126 / 0.058 \pm 0.007$ & $1.000 \pm 0.500 / 0.008 \pm 0.003$ & \\
\hline $10 \mathrm{~B}$ & & $0.893 \pm 0.086 / 0.012 \pm 0.003$ & \\
\hline $11 B$ & $0.778 \pm 0.091 / 0.002 \pm 0.001$ & & \\
\hline $11 C$ & & $0.833 \pm 0.222 / 0.084 \pm 0.009$ & \\
\hline $11 \mathrm{E}$ & & $0.700 \pm 0.218 / 0.002 \pm 0.001$ & \\
\hline $12 \mathrm{E}$ & & $0.667 \pm 0.314 / 0.001 \pm 0.001$ & \\
\hline 13B & & $0.500 \pm 0.265 / 0.001 \pm 0.001$ & $1.000 \pm 0.272 / 0.046 \pm 0.006$ \\
\hline $13 \mathrm{E}$ & & $0.343 \pm 0.128 / 0.001 \pm 0.000$ & $0.956 \pm 0.059 / 0.010 \pm 0.002$ \\
\hline $14 \mathrm{E}$ & & $0.533 \pm 0.172 / 0.001 \pm 0.001$ & $0.800 \pm 0.114 / 0.013 \pm 0.003$ \\
\hline $15 \mathrm{E}$ & & $\mathrm{n} / \mathrm{c}$ & \\
\hline $16 \mathrm{C}$ & & $0.564 \pm 0.134 / 0.002 \pm 0.001$ & \\
\hline $16 \mathrm{E}$ & & $0.667 \pm 0.314 / 0.002 \pm 0.001$ & $1.000 \pm 0.500 / 0.014 \pm 0.004$ \\
\hline $18 \mathrm{D}$ & & $0.600 \pm 0.215 / 0.001 \pm 0.001$ & $\mathrm{n} / \mathrm{c}$ \\
\hline $18 \mathrm{E}$ & & $\mathrm{n} / \mathrm{c}$ & $0.900 \pm 0.161 / 0.006 \pm 0.002$ \\
\hline 19D & & & $0.818 \pm 0.119 / 0.002 \pm 0.001$ \\
\hline $19 \mathrm{E}$ & & & $0.833 \pm 0.222 / 0.003 \pm 0.001$ \\
\hline $20 \mathrm{~A}$ & & & $0.985 \pm 0.040 / 0.028 \pm 0.004$ \\
\hline $21 \mathrm{~A}$ & & & $0.909 \pm 0.047 / 0.006 \pm 0.001$ \\
\hline Total sp & $0.985 \pm 0.007 / 0.066 \pm 0.005$ & $0.928 \pm 0.017 / 0.074 \pm 0.007$ & $0.985 \pm 0.006 / 0.0512 \pm 0.005$ \\
\hline
\end{tabular}

